\title{
Diatom Milking: A Review and New Approaches
}

\author{
Vandana Vinayak ${ }^{1}$, Kalina M. Manoylov ${ }^{2}$, Hélène Gateau ${ }^{3}$, Vincent Blanckaert ${ }^{4}$, \\ Josiane Hérault ${ }^{5}$, Gaëlle Pencréac'h ${ }^{5}$, Justine Marchand ${ }^{3}$, Richard Gordon ${ }^{6,7}$ \\ and Benoît Schoefs ${ }^{3, *}$
}

1 Department of Criminology \& Forensic Science, School of Applied Sciences, Dr. H.S. Gour University (Central University), Sagar Madhya Pradesh, India; E-Mail: kapilvinayak@gmail.com Department of Biological \& Environmental Sciences, Georgia College and State University, Milledgeville, GA 31061, USA; E-Mail: kalina.manoylov@gcsu.edu

3 MicroMar, Mer Molécules Santé, IUML_FR 3473 CNRS, University of Le Mans, Faculté des Sciences et Techniques, Avenue Olivier Messiaen, 72085 Le Mans cedex 9, France;

E-Mails: lngateau@gmail.com (H.G.); justine.marchand@univ-lemans.fr (J.M.)

4 MicroMar, Mer Molécules Santé, IUML_FR 3473 CNRS, University of Le Mans, IUT de Laval, Rue des Drs Calmette et Guerin, 53020 Laval Cedex 9, France;

E-Mail: vincent.blanckaert@univ-lemans.fr

5 ChimiMar, Mer Molécules Santé, IUML_FR 3473 CNRS, University of Le Mans, IUT de Laval, Rue des Drs Calmette et Guerin, 53020 Laval Cedex 9, France;

E-Mails: gaelle.pencreach@univ-lemans.fr (G.P.); josiane.herault@univ-lemans.fr (J.H.)

6 Gulf Specimen Aquarium \& Marine Laboratory, Panacea, FL 32346, USA

7 C.S. Mott Center for Human Growth and Development, Department of Obstetrics \& Gynecology, Wayne State University, 275 E. Hancock, Detroit, MI 48201, USA;

E-Mail: DickGordonCan@gmail.com

* Author to whom correspondence should be addressed; E-Mail: benoit.schoefs@univ-lemans.fr; Tel.: +33-2-438-337-72; Fax: +33-2-438-339-17.

Academic Editor: Alejandro Mayer

Received: 10 December 2014 / Accepted: 17 April 2015 / Published: 29 April 2015

\begin{abstract}
The rise of human populations and the growth of cities contribute to the depletion of natural resources, increase their cost, and create potential climatic changes. To overcome difficulties in supplying populations and reducing the resource cost, a search for alternative pharmaceutical, nanotechnology, and energy sources has begun. Among the alternative sources, microalgae are the most promising because they use carbon dioxide $\left(\mathrm{CO}_{2}\right)$ to produce biomass and/or valuable compounds. Once produced, the biomass is
\end{abstract}


ordinarily harvested and processed (downstream program). Drying, grinding, and extraction steps are destructive to the microalgal biomass that then needs to be renewed. The extraction and purification processes generate organic wastes and require substantial energy inputs. Altogether, it is urgent to develop alternative downstream processes. Among the possibilities, milking invokes the concept that the extraction should not kill the algal cells. Therefore, it does not require growing the algae anew. In this review, we discuss research on milking of diatoms. The main themes are (a) development of alternative methods to extract and harvest high added value compounds; (b) design of photobioreactors; (c) biodiversity and (d) stress physiology, illustrated with original results dealing with oleaginous diatoms.

Keywords: diatom; biotechnology; milking; physiology; stress; biofuel; secondary metabolites

\section{Introduction}

The rise of human populations and the expansion of cities into the countryside contribute to an accelerated depletion of natural resources [1], thereby increasing the prices of these resources in commercial markets and potentially changing the Earth's climate. To overcome difficulties in supplying populations and reducing the resource cost, an intensive search for alternative pharmaceutical, food, high value molecules (HVM), and energy sources, including via genetic engineering and nanotechnology, has started [2-10]. Among the alternative sources, microalgae are promising because using their efficient capacity to photosynthesize, microalgae convert light energy into chemical energy into organic molecules such as carbohydrates and lipids. These molecules are synthesized using the carbon dioxide $\left(\mathrm{CO}_{2}\right)$ from the environment. Among algae, diatoms (Bacillariophyceae) are responsible for a large part (up to $41 \%-50 \%$ ) of the $\mathrm{CO}_{2}$ fixed in oceans [11,12]. In some circumstances, microalgae synthesize secondary metabolites [2,10,13-15] that can have important applications for food, health, cosmetic, energy or pharmaceutical industries. These compounds are called high value molecules (HVM). For instance, the price of the natural carotenoid astaxanthin is expected to reach $\$ 14,000$ US kg${ }^{-1}$ in 2018 [16]. Due to the diversified evolutionary history, the chemical diversity of HVM synthesized by microalgae is broad. Table 1 presents the main storage HVM, including oil content, of some microalgae.

Nowadays, algae are important biotechnological tools with applications in various industrial fields [17-19]. Examples are:

1. wastewater treatment [20-24],

2. biofuel production [24-27],

3. manufacture of fertilizers [28],

4. production of secondary metabolites for pharmaceutical products $[2,29,30]$,

5. production of food for humans [31-33],

6. animal feed [34-36], and

7. medical compounds [2,37-39]. 
Table 1. Main storage compounds and oil percentage of some microalgae.

\begin{tabular}{|c|c|c|c|c|c|}
\hline Phylum & Class & Taxonomy & $\begin{array}{c}\text { Oil Content } \\
\text { (\% d.w.) } \\
\end{array}$ & $\begin{array}{c}\text { High Value } \\
\text { Molecules }\end{array}$ & Reference \\
\hline Chlorophyta & Chlorodendrophyceae & Tetraselmis suecica & $15-32$ & $\begin{array}{c}\text { Carotenoids, chlorophyll, } \\
\text { tocopherol, lipids }\end{array}$ & [40] \\
\hline Chlorophyta & Chlorophyceae & Ankistrodesmus sp. & $28-40$ & $\begin{array}{c}\text { Mycosporine-like amino acids, } \\
\text { polysaccharides }\end{array}$ & [17] \\
\hline Chlorophyta & Chlorophyceae & Dunaliella salina & 10 & $\begin{array}{c}\text { Carotenoid, } \beta \text { carotene, } \\
\text { mycosporine-like amino acids, } \\
\text { sporopollenin }\end{array}$ & [41] \\
\hline Chlorophyta & Chlorophyceae & Dunaliella tertiolecta & $36-42$ & $\begin{array}{c}\text { Carotenoid, } \beta \text { carotene, } \\
\text { mycosporine-like } \\
\text { amino acids }\end{array}$ & [42] \\
\hline Chlorophyta & Chlorophyceae & Neochloris oleoabundans & $35-65$ & Fatty acids, starch & [43] \\
\hline Chlorophyta & Trebouxiophyceae & Botryococcus braunii & $29-75$ & $\begin{array}{c}\text { Isobotryococcene, } \\
\text { botryococcene, triterpenes }\end{array}$ & [44] \\
\hline Chlorophyta & Trebouxiophyceae & Chlorella vulgaris & 58 & Neutral lipids & [45] \\
\hline Chlorophyta & Trebouxiophyceae & Chlorella emersonii & 34 & Neutral lipids & [46] \\
\hline Chlorophyta & Trebouxiophyceae & Chlorella protothecoides & $15-55$ & $\begin{array}{c}\text { Eicosapentaenoic acid (EPA), } \\
\text { ascorbic acid }\end{array}$ & [47] \\
\hline Chlorophyta & Trebouxiophyceae & Chlorella minutissima & 57 & C16- and C18-lipids & {$[48]$} \\
\hline Heterokontophyta & Bacillariophyceae & Nitzschia laevi & $28-69$ & EPA & [49] \\
\hline Heterokontophyta & Coscinodiscophyceae & $\begin{array}{c}\text { Thalassiosira } \\
\text { pseudonana }\end{array}$ & $21-31$ & $\begin{array}{c}\text { Glycosylglycerides, neutral } \\
\text { lipids, TAG }\end{array}$ & {$[50]$} \\
\hline Heterokontophyta & Labrynthulomycetes & $\begin{array}{c}\text { Schizochytrium } \\
\text { limacinum }\end{array}$ & $50-77$ & Docosahexaenoic acid (DHA) & [51] \\
\hline Myzozoa & Peridinea & Crypthecodinium cohnii & 20 & DHA, Starch & [52] \\
\hline Ochrophyta & Coscinodiscophyceae & Cyclotella sp. & 42 & Neutral lipids & [53] \\
\hline Ochrophyta & Eustigmatophyceae & Nannochloropsis sp. & $46-68$ & $\begin{array}{l}\text { EPA, TAG, } \omega-3 \\
\text { LC-PUFA }\end{array}$ & [54] \\
\hline
\end{tabular}

Another reason to be interested in microalga-based biotechnological processes is that they are expected to be more productive per unit surface area of Earth than any cultivated agricultural plant $[55,56]$. For instance, diatom oil production is predicted to be 6-200 times higher than oilseed crops per unit surface area $[27,57,58]$.

Although the use of microalgae for the production of HVM is very recent, microalgae played a crucial role in the formation of crude oil deposits in ocean floors, which are a rich natural source of fossil fuel [59]. This contribution continues today because algae are responsible for a large fraction of the organic carbon being buried on continental margins [60] and oceanic diatoms may even alleviate predicted global warming [61].

In current processes, the algal biomass is harvested, water is removed and HVM are extracted and purified. Milking processes aim to keep the algae alive while HVM are extracted, allowing indefinite repetition of the process. The milking approach will be more environmentally and economically friendly, if it comes to commercial fruition. 
Whatever the biotechnological process used and the final products obtained from the algae, they all start with growing algae to obtain biomass. It is usually considered that microalga growth presents low productivity both in terms of biomass and product formation [62]. Therefore, a first critical issue in developing alga biotechnology is the optimization of culture parameters [63-65] (Figure 1). Once produced, the biomass is harvested and processed according to a dedicated downstream program generally involving dewatering, drying, grinding, extraction, and purification steps [65]. Grinding [66] and extraction [67] are the most popular steps for separation of the HVM from the organisms [65,68] (Figure 1). Obviously, drying and grinding require energy inputs and kill the microalgal biomass that then needs to be repeatedly regrown. In addition, extraction and purification processes generate organic wastes. A critical assessment of current microalga bioprocessing technology reveals that downstream processing also poses a number of important technical and economic challenges $([65,69,70]$ and references therein).

"No harvesting method has yet been identified as being efficient, reliable and at reasonable cost" [71].
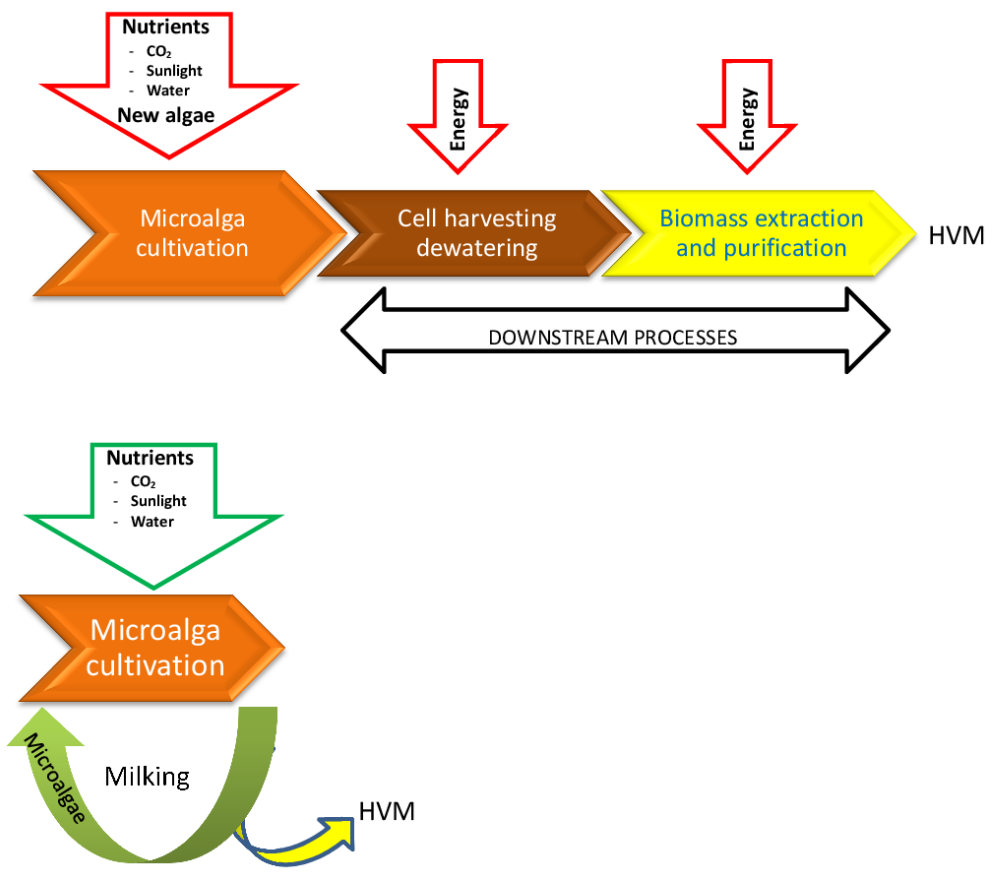

Figure 1. Scheme presenting milking as an alternative to current processes. (Top): Current processes are systems that require starting new microalgal cultures for each batch of HVM, with fresh nutrients; (Bottom): Milking only requires inputs of carbon dioxide and water used up in producing HVM, and thus is closer to a closed system.

For instance, it is estimated that downstream operations costs usually represent $50 \%-80 \%$ of the total processing costs [72-78]. Moreover, some of the currently proposed downstream processes are not economically sustainable, because they depend on waste $\mathrm{CO}_{2}$ [79-83], which is a nonstarter for large-scale production. This can be seen as follows. In 2011, 21\% of $\mathrm{CO}_{2}$ emissions were industrial, while $22 \%$ were due to transport, and the latter figure is projected to reach $40 \%$ by 2035 [84]. This means that even with $100 \%$ utilization of industrial $\mathrm{CO}_{2}$ waste, there is not enough to be converted to 
biofuel for all transport now, let alone by 2035. So although the use of atmospheric $\mathrm{CO}_{2}$ may slow HVM production [85], the use of waste $\mathrm{CO}_{2}$ is at best a stopgap.

Altogether, it seems urgent to develop alternative downstream processes. Among the possibilities, the concept of milking was introduced by Frenz and collaborators in 1989 [86] to describe the extraction of hydrocarbons from the green algae Botryococcus braunii Kützing (Trebouxiophyceae) by exposing the cells for a short time to hexane (cf. [87]). Ramachandra et al. [27] have pointed out the analogy to grinding up cows to extract dairy milk, which has been acknowledged, but regarded as inevitable:

"Plenty of organisms use those same inputs-All photosynthetic microalgae, for example. But you can't milk them like a cow. You have to crush them" [79].

The milking concept specifies that the extraction should not kill the cells. Consequently, milking does not require the constant need of culturing and re-growing the entire stock of algae, which has a typical timescale of a few hours to weeks. If only hydrocarbon HVM were milked, then the need for nitrogen/phosphorus fertilizers would be reduced [88] or eliminated.

In some of the literature the distinction that we are now making between extraction and milking was not considered, so that what we are calling extraction was labeled as "milking" [67]. Similarly, we previously lumped secretion and extraction under "milking" [27,89]. We think that careful distinctions between these approaches will make for better dialogue. Thus we define:

- Milking as the removal of a specific set of products without killing the organism, in such a way that it can be milked again at a later time.

- Extraction as the removal of a specific set of products without concern about the survival of the organism, generally leaving an organic residue.

- Secretion or spontaneous oozing as the active dumping of a specific set of products by an organism into its surrounding environment.

In this manuscript, we propose food for thought toward the development of milking of microalgae, particularly diatoms. To reach our goal, the main grounds for thought that we have identified are (a) development of alternative methods to extract and harvest HMV; (b) design and functioning of photobioreactors; (c) biochemodiversity and (d) diatom (stress) physiology. They are discussed separately in this contribution and, when possible, illustrated with original results dealing with diatoms accumulating lipids. These algae are referred to as oleaginous diatoms. Although recent reviews [90,91] addressed several points discussed in this contribution, none of them focused on diatoms and milking.

\section{Development of Alternative Processes to Extract and Harvest High Value Molecules (HVM)}

The key element of milking is finding a way to extract HVM without killing the HVM-producing cells. This concept was first applied to higher plants by milking, for instance, rubber 2000 years ago [92]; maple syrup historically [93] and prehistorically [94,95]; turpentine as long ago as Hippocrates [96]; and, more recently, halophilic bacteria [97,98] and microalgae. The first applications with algae used biocompatible solvents to extract HVM (reviewed in [27,62]). Recently, Gillet [99] calculated the molecular dynamics of the plasma membrane during milking using organic solvents. 
The conclusion of this theoretical study agreed with earlier experimental results obtained by Zhang et al. [67] and showed that hexadecane is the best organic solvent to milk lipids from Nannochloropsis sp. (Eustigmatophyceae) (cf. [100]). However, solvents alone are usually not efficient for HVM extraction if the cell wall is too robust [101]. In this case, HVM extraction should be assisted by other methods. It is important to recall here that the efficiency of these processes may depend on the growth stage of the cells. Table 2 presents an overview of these different potential technologies with a summary of their strengths and weaknesses, although without any pretention of being exhaustive. The aim of this section is to provide a detailed analysis of these possibilities in the framework of a milking strategy. We do not consider destructive processes, such as microwaving and heating [102], though in moderation they might also serve to induce milking.

Table 2. Extraction processes potentially applicable for milking of microorganisms.

\begin{tabular}{|c|c|c|c|c|}
\hline Milking Process & Microorganism & Advantages & Disadvantages & $\begin{array}{c}\text { Ability to Keep } \\
\text { Cells Alive } \\
\end{array}$ \\
\hline $\begin{array}{l}\text { Biocompatible } \\
\text { organic solvents }\end{array}$ & Microalgae $[67,100]$ & $\begin{array}{c}\text { Improvement of } \\
\text { lipid production } \\
\text { Positive effect on growth } \\
\end{array}$ & $\begin{array}{l}\text { Not environmentally friendly } \\
\text { Possible toxic mechanism }\end{array}$ & $\begin{array}{l}\text { Yes, when using } \\
\text { hydrophobic solvents }\end{array}$ \\
\hline $\begin{array}{l}\text { Pulsed electric } \\
\text { field (PEF) }\end{array}$ & $\begin{array}{l}\text { Yeast [103] } \\
\text { Microalgae [104-107] } \\
\text { Cyanobacteria [108] }\end{array}$ & $\begin{array}{c}\text { High extraction yield } \\
\text { Adjustable PEF parameters } \\
\text { Not an energy-intensive process } \\
\text { Large-scale process } \\
\text { demonstrated } \\
\text { Continuous process }\end{array}$ & $\begin{array}{l}\text { Effect of electric pulsation } \\
\text { is size dependent }\end{array}$ & $\begin{array}{l}\text { Yes, but depends on } \\
\text { the PEF parameters }\end{array}$ \\
\hline Spontaneous oozing & $\begin{array}{c}\text { Microalgae [109] } \\
\text { Bacteria [110-112] } \\
\text { Cyanobacteria } \\
\text { [113-115] }\end{array}$ & $\begin{array}{l}\text { Not an energy-intensive process } \\
\text { Possibility of scaling up } \\
\text { Application in solar panels }\end{array}$ & Slow oozing of HVM & $\begin{array}{l}\text { Yes, it is a natural } \\
\text { mechanism }\end{array}$ \\
\hline \multicolumn{5}{|l|}{ Mechanical methods } \\
\hline -sonication & $\begin{array}{c}\text { Microalgae [116,117] } \\
\text { Cyanobacteria [118-120] }\end{array}$ & Improvement of lipid recovery & $\begin{array}{l}\text { Cellular damage apoptosis } \\
\text { Thickness of the cell wall }\end{array}$ & No \\
\hline -pressure & Microalgae [this work] & $\begin{array}{l}\text { Not an energy-intensive process } \\
\text { Weak pressure to be used } \\
\text { (below } 750 \mu \mathrm{N} \text { ) }\end{array}$ & $\begin{array}{c}\text { Large-scale process not } \\
\text { demonstrated } \\
\text { Process needs to be improved }\end{array}$ & $\begin{array}{l}\text { Yeswhen using low } \\
\text { pressure }(<750 \mu \mathrm{N})\end{array}$ \\
\hline -centrifugation & Diatoms [work in progress] & $\begin{array}{c}\text { Continuous process } \\
\text { Application in solar panels }\end{array}$ & Requires energy & Not yet tested \\
\hline $\begin{array}{l}\text { Membrane-bound } \\
\text { protein pumps }\end{array}$ & Bacteria $[121,122]$ & $\begin{array}{c}\text { Oozing of HVM } \\
\text { Lower toxicity of } \\
\text { overexpressed HVM } \\
\text { High rate growth } \\
\text { Possibility of scaling up }\end{array}$ & $\begin{array}{l}\text { Metabolism engineering } \\
\text { Organic phase needed for } \\
\text { solubilization of water } \\
\text { insoluble HVM }\end{array}$ & Yes \\
\hline
\end{tabular}




\subsection{Pulsed Electric Field}

Electroporation has been applied to diatoms and other microalgae, albeit primarily to allow genetic transformation [123-128]. However, the application of trains of electric pulses can also be used to favor the release of HVM from cells. In this method, cell membranes are punctured by electric pulses, subsequently allowing the cell components to ooze out. The method was first established with yeast [103,129] and more recently applied to photosynthetic organisms such as cyanobacteria [108] and microalgae [104,105]. The "punctured" cells then heal and remain viable and the same batch of algae can be reused for further extraction of HVM [106]. Because electric pulses can have deleterious effects in bacteria [130], algae [131] and mammal cells [132], such as irreversible electroporation, the choice of the characteristics of the electric pulses such as length, intensity, polarity, frequency of repetition, etc. require a compromise between milking efficiency and algal survival. The tuning of physical parameters is of importance because the effect of the pulsed electric field is cell size dependent: the smaller the cell, the stronger the electric treatment [105,133,134]. Repetitive $2 \mathrm{~ms}$ long electric pulses of alternative polarities with field strength of 3 and $6 \mathrm{kV} / \mathrm{cm}$ were capable of significantly inducing the extraction of cytoplasmic proteins from two freshwater microalgae, Chlorella vulgaris Beyerinck (Trebouxiophyceae) and Haematococcus pluvialis Flotow (Chlorophyceae), both with rigid cell walls [105]. A post-pulse incubation step was found to be necessary in order to allow oozing, but also to permit the algae to recover between trains of electric pulses $[105,107,135]$.

\subsection{Spontaneous Oozing}

Currently, there are proprietary reports that some bacteria [110-112], green algae [62,86] and genetically engineered cyanobacteria [113-115,136,137] can secrete lipids [82] from their cytoplasm to the external environment. Botryococcus secretes its oil into a kind of cell wall called the outer matrix [87]. Surface properties may prove important in secretion [138]. Very recently, Vinayak et al. [109] reported that a small diatom strain (14-18 $\mu \mathrm{m}$ long and 6-7 $\mu \mathrm{m}$ width), Diadesmis confervaceae Kützing (Figure 2), producing 14.6\% lipid content, exudes lipid droplets into the culture medium. The mechanisms involved in oozing are not yet determined. The droplets accumulate either in the chloroplasts (plastoglobules) or/and in the cytoplasm (oleosomes) (see also Section 4).

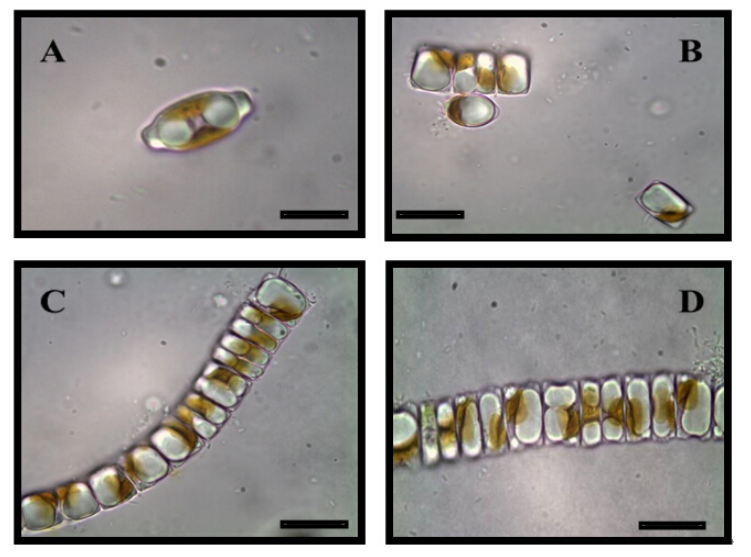

Figure 2. Diadesmis confervaceae in solitary and chain forms as observed under $100 \times$ oil immersion. Note oozed oil droplets in panel C. Cf. [109]. Scale bar: $10 \mu \mathrm{m}$. 


\subsection{Mechanical Pressure}

In algae lacking a natural oozing mechanism, one could assume that exerting a mechanical pressure, such as ultrasound or touch, could force HVM to come out of the cells. Similarly to electric pulse treatment (Section 2.1), ultrasound has been used in processes for improving the extraction of carotenoids (Haematococcus pluvialis [139,140]), chlorophyll (Chlorella sp. [141], Dunaliella [142,143]), and lipid (Chlorella vulgaris [116]) (for a review, see [144]). Because ultrasound effects can be harmful (death [118], nonviable cellular damage [119], or induction of programmed cell death [120]), the characteristics of the ultrasound treatment should be chosen to keep the cells alive and, thus, be qualified for inclusion in a milking process. For instance, Araujo et al. [116] reported that ultrasound treatment of Chlorella vulgaris produced a significant improvement in lipid recovery when compared to the yield reached in the absence of the treatment. However, the efficiency of the treatment depends on the cell wall strength as only a weak improvement was recorded with Scenedesmus, a Chlorophyceae taxon with tougher cell walls [117,118]. For instance a $20 \mathrm{~min}, 20 \mathrm{kHz}$ treatment causes death of the cyanobacterium Microcystis aeruginosa Kützing [118].

Diatom cells present the unique feature of being enclosed in a hydrated silicon dioxide cellwall denoted the frustule. Frustule shape and decorations are widely diversified [145,146]. In addition, each diatom has an imperfect bilateral symmetry since one of the frustules is slightly larger than the other, allowing one valve to fit inside the edge of the other. Because of this and the robustness of the frustule, mechanical methods could provide a very powerful method favoring the release of HVM. To test this possibility, diatoms harvested in Georgia, USA (see Section 3) were placed in water on a rigid surface and covered with an $18 \times 18 \mathrm{~mm}^{2}$ coverslip and pressed with a microbial needle. Pressure was applied in the middle of the coverslip until water flow out from under the coverslip ceased. All expressed water remained on the slide at the edges of the coverslip. The population remaining under the coverslip was then visually scanned and changes such as breaking of the cells or release of oil were documented. Where possible to identify them, the same cells were scrutinized. With the mechanical pressure on the cover slip live diatoms were not visibly broken or harmed and the release of oil from Terpsinoё musica Ehrenberg was recorded at least twice. Interestingly, Terpsinoë musica naturally produce zigzag colonies (Figure 3, panel A,E) in which the individual cells are attached by organic pads secreted from the terminal apical pore fields (Figure 3A arrow and 3B) [147]. The observations reported here suggest that the oil is also released through the apical pore field, which is also known to be used for the release of carbohydrates [148]. It would be interesting to test other diatoms with an apical pore field [149] for their oozing capacity. Although the force that has to be exerted on a live diatom for expressing oil has not yet been measured, we can assume that it is considerably less than the force required to break an isolated diatom valve. Hamm et al. [150] presented mechanical properties of various diatoms under tensile and compressive stresses, and reported the breaking force for an isolated diatom valve to be $750 \mu \mathrm{N}$. 


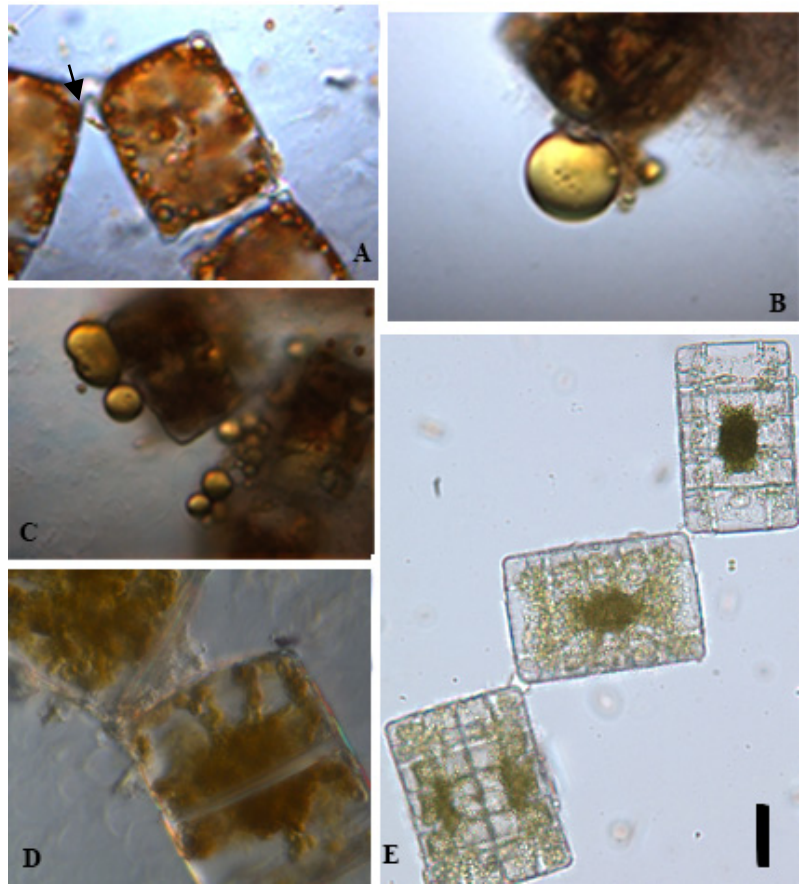

Figure 3. Terpsinoë musica is a freshwater diatom that releases oil under mechanical pressure on the cover slip. Scale bar $=10 \mu \mathrm{m}$. (A) Freshly collected Terpsinoë musica; (B,C) Terpsinoё musica cells kept 7 days in an incubator released oil when mechanically pressed; (D) Terpsinoë musica divides 10 days after oil release; (E) Zigzag colony of Terpsinoё тиsica.

\subsection{Centrifugation}

At the time of writing, we have just started work on release of oil from diatoms via centrifugation, which will be reported later. We have yet to determine if the centrifugal force that releases oil is lower than that which kills them. If so, the centrifugation could become a milking technique. Centrifugation is presently used for algal separation [151]. In sea urchin eggs centrifuged at $9000 \times g$ the lipids rise to the centripetal end and exert enough buoyancy to divide the egg in two [152].

\section{The Design and Functioning of Photobioreactors}

In microalgal biotechnology, the cultivation of biological material is considered as one of the major constraints to commercial development, despite the fact that maximum doubling rates between 2 and 5 day $^{-1}$ have been reported $[27,153]$. The simplest method for algae production is the open raceway pond: shallow, circulating, open bodies of water that are exposed to the elements and use the natural energy of the sun $[154,155]$. There are several advantages to this design, such as less material and capital being required for operation, but there are many drawbacks [65,156-158]. Primarily, the open nature of a raceway pond leaves it vulnerable to contamination, low volumetric productivity and poor temperature and light intensity control [159]. Photobioreactors (PBRs) allow much more control than open raceway ponds due to their closed systems $[73,74,160,161]$. They are usually made of glass or plastic and can be used outside with natural sunlight as well as indoors with artificial light such as light-emitting diodes (LEDs) [162,163]. The three main designs, annular PBRs, which are large 
columns, flat panel PBRs, and tubular PBRs, allow for laboratory conditions at all times. Yet, this approach is considerably more expensive than the open raceway pond [65,76,164,165]. As far as oil production is concerned, for all methods to be economically viable, they either have to be cheaper than traditional gasoline and be seamlessly introduced into an infrastructure based on fossil fuels, or they need to be protected by tariffs or embargos on imported oil [166] and/or subsidized relative to fossil oil. To involve the milking philosophy into microalgal biotechnology, downstream processes have to be modified to allow milking operations such as electric pulses to occur.

One can also propose innovative photobioreactors such as the live diatom solar panel [27]. Such a panel may require sandwiching diatoms in a series of polymeric microchannels that can be squeezed by increasing pressure on the backside of the channel. Forces of this magnitude can be produced in a microfluidic environment by electrical and mechanical means. The former mechanism can utilize Maxwell stresses induced by specifically designed electrode systems [167,168]. One suitable material for such polymeric channels is polydimethylsiloxane (PDMS), which can covalently bond to glass during the solar panel manufacturing process, and can be prepared with a long-lasting hydrophilic surface suitable for cell culture [169]. PDMS is impermeable to water but would transmit air including much needed $\mathrm{CO}_{2}$ [170] to diatoms. The front of the glass-PDMS chambers can provide a fluidic environment to diatoms, while the backside of the PDMS chambers can be interfaced with gas channels. Increasing pressure in the gas channels would push the flexible PDMS and squeeze diatoms between the PDMS and glass substrates, possibly releasing oil. Large-scale systems with thousands of individually controlled PDMS micro-valves have been demonstrated before [171]. The diatom solar panel envisioned would require only several valves and the entire system could be fabricated cheaply, making this proposed technology cost effective. Separation of milked oil from the diatoms could perhaps be facilitated by buoyancy, pumping, centrifugation and/or the use of spatial gradients or step functions of the surface hydrophobicity of the PDMS channels [172]. If the diatoms used in diatom biofuel solar panels do not spontaneously secrete HVM, then a power source to apply force to the live diatoms to milk them for biofuel (see Section 2) would be needed (possibly using solar electric power generated in the same panel). Instead of bulk solvent extraction, the algal cells could be left in place and, lipids and/or other HVM removed by microfluidics [173].

In this review our focus is on the use of living diatoms to produce biofuel and other compounds. It is important to distinguish this from the use of nonliving diatom frustules in novel electricity-generating solar panels [174]. Of course, both could be combined in a single panel.

Solar panels containing living diatoms or other algae could go on rooftops, for example, and we have estimated that surface areas of 10 square meters per person might suffice to match USA rates of gasoline consumption [175], especially if the algae could be selectively bred [176] or genetically engineered for octane production [177] or other low carbon and volatile compounds [27]. Diatom solar panels also have the advantage of local gasoline production, reducing the need for a distribution system, storage of energy overnight in liquid form instead of in heavy batteries that last only a few years [178] and could make use of species adapted to local conditions [179]. While developing new processes, especially algal solar panels [27,180], one should keep in mind that algae that are in use must stay alive. Species should therefore be identified as, for instance, from geothermal waters that are thermo-resistant (as are some green microalgae [181]) or thermophilic [27] (as some diatoms are [182-185]). 


\section{Diatom Chemobiodiversity}

Tens of thousands of strains of microalgae have been described, millions of species are expected to exist $[186,187]$, and new species, including diatoms, are continuously being described. In contrast to this amazing biodiversity, no more than 10 species are commonly used at the commercial level, regardless of the geographical location of the producing company, which is often done outdoors [65,188]! These species include the diatoms Phaeodactylum tricornutum and Odontella aurita [16]. Thus another way forward is the development of more strains of industrial interest [173]. This is especially important if HVM production units are widely distributed from the geographic point of view as prospective studies have predicted [189]. In other words, promising strains must be optimized for local climatic conditions, and media optimized for those strains [190]. Bloom diatoms, for example, may be particularly good oil sources [191], and perhaps invasive diatoms [192] would be worth considering. There are several nonexclusive possibilities for finding such species/strains: (a) strain selection, (b) synthetic biology and (c) exploring biodiversity. Study of biodiversity can also lead to the discovery of new HVM.

\subsection{Strain Selection}

In the introductory paragraph of this section, we underlined how it will be quite important to use dedicated species for the production of HVM. Because methods for synthetic biology are still under development for microalgae (see Section 4.3), screening remains one of the most promising methods for the selection of dedicated species provided a selection criterion has been determined and a fast and low cost detection method is available [193]. For instance, Kopecky et al. [194] screened algal collections for the capacity of green algae to synthesize secondary carotenoids. Using high light stress as a selection pressure and thin-layer chromatography as the analytical method several putative, interesting strains were characterized for their secondary pigment content. Recently, nondestructive methods such as Fast-Fourier InfraRed (FT-IR) spectroscopy have been developed to characterize the biochemical contents of microalgae [195-197].

The selection pressure need not be a natural factor. Bougaran et al. [198] developed a nongenetically modified organism mutation-selection method based on UVC irradiation (at $254 \mathrm{~nm}$ wavelength) followed by flow cytometry selection to isolate an Isochrysis affinis galbana population overaccumulating neutral lipid (with a productivity increase of 80\%). Robert et al. [199] used the herbicide metolachlor, a member of the chloroacetamide family of compounds, to select diatom strains with hyperaccumulation of long-chain polyunsaturated fatty acids (PUFA). PUFA are health-benefitting molecules $[2,200]$. This herbicide was chosen because it is an inhibitor of the fatty acid ester-type (FAE) elongase biosynthesis of very long-chain fatty acids in microalgae [201]. For a review on the metabolic pathways leading to very long chain fatty acids, see [14].

\subsection{Exploring Biodiversity}

It is usually admitted that biodiversity constitutes the richest source of bioactive molecules [202]. Unfortunately, since World War II, the search for such compounds from natural sources has been gradually replaced by synthetic and combinatorial chemistry (for a review, see [203]). In the recent 
past, many different scale bioprospecting programs such as the Aquatic Species Program [204] or Tara Oceans Cruise [205] have aimed to find new HVM from nature [206-208]. The Aquatic Species Program identified 50 promising microalgal strains for biofuel production among which $60 \%$ are diatoms. This number is far greater than the number of diatom species that have been used so far in microalga biotech. This shift back to bioprospecting programs partly relies on the assumption that living organisms are a storehouse for HVM that are just waiting to be discovered. Theoretical investigations of the relationship between biological and chemical diversities revealed that it is unlikely that a fine combing of global resources sharing similar biological niches will discover interesting species unless they are distant from the phylogenetic point of view, as shown for the plant-herbivore relationship [209]. Therefore, bioprospecting would be more successful in screening biological resources, including microalga collections, from diversified ecological niches such as hot sources [181,185], depths of the ocean [181,210], or very saline or polluted waters [145] with a search for organisms that are phylogenetically distant from one another [211]. Once new strains have been collected from the natural environment, they should be selected according to defined criteria through a screening program as explained in Section 4.1 (phytohormones [212], lipids [213]). For instance, various places in Georgia were sampled for diatoms from March to July 2011 in triplicate (Table 3).

Table 3. Site locality and identification for sites collection within southeastern USA, temperature $(\mathrm{T}), \mathrm{pH}$, percent dissolved oxygen (DO \%) and conductivity $\left(\mu \mathrm{S} \mathrm{cm}^{-1}\right)$, mean \pm SE.

\begin{tabular}{cccccccc}
\hline Location & No. & T $\left({ }^{\circ} \mathbf{C}\right)$ & pH & DO \% & Conductivity & Latitude & Longitude \\
\hline Lake Sinclair Power Plant & 1 & $23.5 \pm 4.2$ & $7.0 \pm 0.2$ & $9 \pm 2.52$ & $32 \pm 3.6$ & 33.20 & -83.30 \\
Lake Sinclair, Goat Island & 2 & $21.8 \pm 1.3$ & $8.5 \pm 0.1$ & $110 \pm 14.1$ & $67 \pm 6.2$ & 33.16 & -83.23 \\
Lake Sinclair at Dam & 3 & $19.9 \pm 6.1$ & $7.8 \pm 0.8$ & $69 \pm 8.2$ & $46 \pm 7$ & 33.14 & -83.20 \\
Oconee River at Dam & 4 & $23.8 \pm 5.1$ & $7.1 \pm 2.1$ & $61 \pm 11.1$ & $82.6 \pm 1.4$ & 33.14 & -83.20 \\
Oconee River Greenway & 5 & $20.2 \pm 9$ & $7.2 \pm 1.6$ & $75 \pm 2.6$ & $78.3 \pm 6.9$ & 33.08 & -83.21 \\
$\quad$ Fishing Creek & 6 & $22.4 \pm 3.2$ & $6.3 \pm 0.4$ & $89 \pm 8.2$ & $29.2 \pm 11.4$ & 33.08 & -83.22 \\
$\quad$ Tobler Creek & 7 & $22.1 \pm 2.1$ & $7.2 \pm 0.2$ & $45 \pm 10.6$ & $85 \pm 5.3$ & 33.12 & -83.27 \\
$\quad$ Andalusia pond & 8 & $23.5 \pm 1.8$ & $6.8 \pm 0.5$ & $76 \pm 9.6$ & $24.3 \pm 1.8$ & 33.13 & -83.27 \\
Bartram forest pond & 9 & $19.5 \pm 3.2$ & $7.4 \pm 1.3$ & $58 \pm 12.6$ & $78.5 \pm 1.6$ & 33.02 & -83.21 \\
Savannah River at Port & 10 & $25.5 \pm 4.4$ & $7.6 \pm 0.4$ & $86 \pm 9.7$ & $8204 \pm 125.4$ & 32.17 & -81.16 \\
$\quad$ Wentworth, GA & & & & & &
\end{tabular}

Five lentic (three locations at Lake Sinclair, ponds at Andalusia Farm and Bartram Forest, Baldwin County) and five lotic locations were sampled; two on Oconee River and one each at Savannah River, Tobler and Fishing Creeks, in southeastern Georgia, USA (Table 3), all locations being freshwater with the exception of the samples from the Savanna River at Port Wentworth, GA with conductivity higher than $2000 \mu \mathrm{S} \mathrm{cm}^{-1}$. Each habitat sample was taken as composite vegetation; water and sediment samples were taken following the loose sediment collection technique in EPA's periphyton protocols [214]. Representatives of 24 diatom genera were identified from the natural samples with 314 taxa identified to species from all samples. The brackish sample from the Savannah River estuary was the most diverse with 167 diatom species. The freshwater diatom community was dominated by 
representatives of pennate genera including Nitzschia, Fragilariforma, Synedra and Eunotia (see Supplementary Table S1).

Cell size and the relationship between size and oil production were tested with the data. Only 106 individual cells out of thousands visually scanned (representing 341 species) had visible lipid droplets. Small diatoms dominated the size distribution of those diatoms containing lipid droplets and the frequency numbers above the highest potential average of oil content within that category (Figure 4). Only representatives of the genera Craticula, Pinnularia, and Eunotia from natural freshwater conditions and Pleurosira and Terpsinoe from the brackish environment had visible lipid droplets. None of the araphid diatoms observed had visible lipid droplets. Some pennate diatoms such as Pinnularia and Craticula representatives were shown to have less than $10 \%$ volume concentrations of oil within the first 7 days (see also Supplementary Data S2).
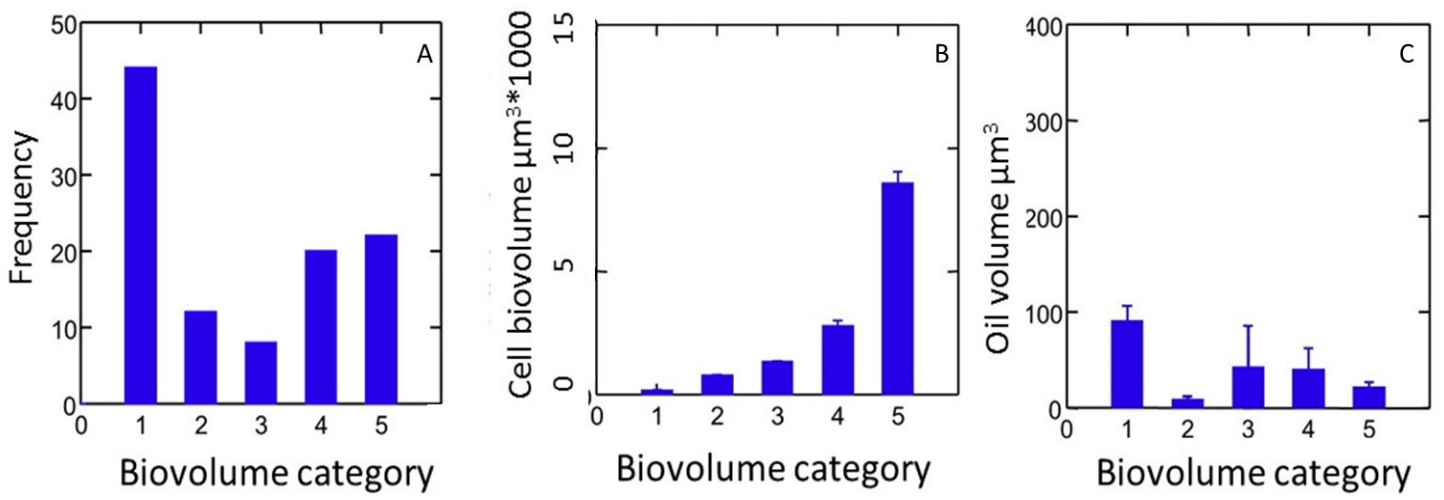

Figure 4. Frequency of cells in five diatom cell biovolume categories, for cells that contained lipid droplets. (A) Frequency of cells in 5 diatom cell biovolume categories, for cells that contained lipid droplets; (B) Average biovolume within each cell biovolume category; (C) Oil content within each cell biovolume category.

\subsection{Toward Dedicated Producers Using Synthetic Biology}

Despite the promises of studying chemobiodiversity for industrial processes, the chance of finding, in a short time, perfect strain(s) adapted to the ad hoc industrial environment, growing quickly and producing high amounts of specific compounds is as difficult as finding a needle in a haystack. This reasoning led to the concept of engineered cells as HVM factories. In this concept, such cells would be tailored to be capable of producing dedicated HVM and could be used to tackle some of society's most important and/or toughest challenges [215].

Diatoms have been successfully transformed by microprojectile bombardment (Chaetoceros sp. [216], Cyclotella cryptica [217], Cylindrotheca fusiformis [218,219], Fistulifera sp. [220], Navicula saprophila [217], Phaeodactylum tricornutum [221,222], Thalassiosira pseudonana [219]. Unfortunately, microprojectile bombardment is costly and does not allow a high transformation efficiency. To overcome these difficulties, electroporation transformation protocols have been developed for Phaeodactylum tricornutum [126,128,223] and Chaetoceros gracilis [224]. They allow a maximum transformation efficiency $\left(2.8 \times 10^{-5}\right.$ cells $)$ comparable to the ones obtained with Chlamydomonas sp. $\left(2.0 \times 10^{-5}\right.$ cells [225]) or Nannochloropsis sp. $\left(1-2 \times 10^{-5}\right.$ cells [226,227]). 
Several publications established the benefit of genetic engineering for enhancing the production of HVM [228,229]. For instance, Trentacoste et al. [230] were successful in increasing the lipid metabolism in the diatom Thalassiosira pseudonana by targeting knockdown of acyltransferase enzyme locus Thaps3_264297 homologous to human CGI-58, having a conserved histidine-glycine dipeptide, without affecting the growth and viability of Thalassiosira pseudonana (whose metabolic network for lipids has been constructed [231]). Using a new dedicated method, Daboussi et al. [232] targeted the diatom model organism Phaeodactylum tricornutum and used zinc finger nucleases, meganucleases, and transcription activator-like effector nucleases (TALEN) to edit Phaeodactylum tricornutum by inducing targeted mutagenesis of certain genes responsible for HVM production. This led to formation of a mutant diatom Tn 19745_1 that produces 45 times more TAG than the control and further increased the HVM production when grown in nutrient-stressed media. However, despite the tremendous reported enhancement, the cost of production of lipids is very high and the process remains uneconomical. In addition, the accumulation of high amounts of HVM inside the cell can prove to be toxic at a level still too low to be relevant for the industry. This is the case for isopentenol, the platform molecule precursor of isoprenoids (for biosynthetic pathways, see [14] for which the lower limit is of the order of $1 \mathrm{~g} \mathrm{~L}^{-1}$ [122]. Therefore, one should see milking as more than an alternative possibility to get more sustainable blue biotech, i.e., as a mandatory process.

Recently, the concept of the cell factory has been expanded to synthetic biology, a branch of life science aiming to develop new biosynthetic pathways for the production of HVM, programmable logic controls to regulate and optimize complex cellular functions, and robust strains. For instance, Harrison and Dunlop [233] have developed a mathematical model for cell growth and biofuel production that involves a synthetic feedback loop using a biosensor to control efflux pump expression. Such a possibility is obviously critical because the cell toxicity of the accumulated HVM can be high (bacteria [234], cyanobacteria [235]). Thus, the export of accumulated HVM out from the producing cells constitutes a major challenge in achieving high-level production. To reach this goal, transporters facilitating the exportation of HVM should be identified at the molecular level and eventually heterologously expressed in the microalgae to be milked. Of course, the resulting protein(s) have to be addressed to the plasma membrane (see [236]). The proof of concept for such a strategy has been obtained by overexpressing several types of transporting systems in the plasma membrane of Escherichia coli in order to export isoprenoids [121,122] (Table 4).

To this end, knowledge of diatom physiology has to be deepened to understand the biochemical, cellular and molecular mechanisms sustaining the production of HVM as well as those that may be triggered by milking. This is especially true for carbon metabolism because HVM are mostly made of carbon and hydrogen atoms [236] (see Section 5). En route to this goal, the generation of robust mathematical models, able to precisely and accurately describe the metabolic state of a cell will constitute a major advantage, especially if they are able to integrate the different levels of complexity that the production of HVM requires [236,237]. Actually, the $\mathrm{CO}_{2}$ concentration and nutrient sources must be investigated and optimized for each microalgal strain [238]. 
Table 4. Cloning of efflux pumps facilitate the excretion of synthesized lipids out from bacteria cells. "Pro/cons" stands for advantages and disadvantages.

\begin{tabular}{|c|c|c|c|c|c|}
\hline Type of Transporter & Origin & Host Cells & $\begin{array}{c}\text { Molecules } \\
\text { Transported } \\
\end{array}$ & Pro/Cons & References \\
\hline $\begin{array}{l}\text { Resistance-nodulation-cell } \\
\text { division (RND) family }\end{array}$ & $\begin{array}{c}\text { Gram-negative } \\
\text { bacteria, similarities } \\
\text { with cyanobacteria }\end{array}$ & Escherichia coli & limonene & $\begin{array}{l}\text { Pro: increase the } \\
\text { excretion of limonene } \\
\text { Con: Large tripartite } \\
\text { protein complex [239] }\end{array}$ & [122] \\
\hline $\begin{array}{l}\text { ATP-binding cassette } \\
\text { (ABC) }\end{array}$ & Bacteria & Escherichia coli & $\begin{array}{c}\text { carotenoids, } \\
\text { squalene, } \\
\text { botrycoccene }\end{array}$ & $\begin{array}{c}\text { Pro: present in all } \\
5 \text { kingdoms; import or } \\
\text { export molecules and } \\
\text { ions across cell } \\
\text { membranes }\end{array}$ & {$[121,240,241]$} \\
\hline Formate transporter (focA) & Escherichia coli & Escherichia coli & formate & & [242] \\
\hline
\end{tabular}

\section{Understanding of Diatom (Stress) Biology}

Being one of the most important world net primary producers, diatoms play an important ecological role $[11,243]$. From the evolutionary point of view, the history of diatoms is much more complex than for green algae. It is out of the scope of this paper to detail the different roads through which diatoms have evolved. The interested reader is invited to read recent specialized reviews on this topic [244,245]. To be convinced of this complexity, it is enough to mention that diatom evolution has involved several endosymbiotic events, including with a cyanobacterium and a red alga [246] together with a chlamydial invasion [247]. The gene enrichments provided by these events resulted in a unique set of metabolic and regulation networks [248] that certainly helped diatoms to colonize every type of ecological habitat such as freshwater, brackish, marine and hypersaline environments with wide ranges of temperature, $\mathrm{pH}$, and nutrient availability. Some may be considered extremophiles [145,249]. This colonization capacity reflects a very flexible metabolism allowing them to adapt to various environmental constraints [145,250-253]. Long-term adaptation mechanisms often involve metabolic shifts, consisting in the production of secondary metabolites [53,163]. Because stress conditions such as salinity [254], nutrient deficiency, temperature and high light stress [255] are "interpreted" by the algae as "dangerous" [91], they accumulate high-energy molecules such as carotenoids and/or lipids $[13,53,254,256]$. For instance, a nitrogen or silicon depletion stress has been shown to increase oil production in diatoms by a factor of 2 or 3 of their average dry weight [257-259]. Desiccation can cause algae to create thick mucus sheaths that are often found to contain starch or oil [260]. Diatoms can store energy in the form of chrysolaminarin or as lipids [261], so we will have to learn how to bias production towards oil. It is usually admitted that microalgal division activity competes with HVM accumulation [53,262,263]. Algae with high oil content, such as Botryococcus, grow slowly and can only be harvested a few times a week whereas those containing low amounts of oil, such as Dunaliella, divide faster and can be harvested daily. For this reason, most industrial applications use algal strains with 20\%-40\% lipid content [65]. To ensure a high division rate, diatoms can rely on a greater ability to fix $\mathrm{CO}_{2}$ than other phytoplanktonic groups [264]. For instance, under fluctuating light intensities, the diatom Phaeodactylum tricornutum was nearly twice more efficient than the green alga 
Chlorella vulgaris [60]. This suggests a strong regulation in the fate of photosynthetically fixed carbon [236,265]. This means that any stress impacting negatively on growth should activate HVM production [13,14,53,266]. For instance, lipid production in Chlorella emersonii could be as high as $63 \%$ DW when grown under nitrogen stress (Table 1). However, conditions allowing growth and neutral lipid accumulation were found recently for the green microalga Neochloris oleabundans [267] (cf. [230]). In the philosophy of milking, the rate of alga division does not seem very critical because the HVM production will not rely on biomass production but more on the carbon flux through the dedicated pathways, as observed with an Escherichia coli strain secreting isoprenoids thanks to the an overexpressed $\mathrm{ABC}$ transporter [121].

In the context of lipid milking, the formation and storage of lipids is of course of particular interest. Diatoms, as other microalgae, store lipids into oleosomes [268] (also called spherosomes, lipid droplets, lipid bodies, oil droplets, etc.), the amount of which increases under stress conditions (green algae [269]; diatoms [109,256]). In diatoms, lipid synthesis involves the chloroplast and the endoplasmic reticulum (for a review, see [14]). However, as in higher plants [14], there is probably no direct pathway for fatty acids to move from chloroplasts to oleosomes as is usually assumed by many complex interconnected reactions involving the endoplasmic reticulum. A first indication for such a view has been deduced from a proteomic study of isolated oleosomes from the diatom Fistulifera solaris JPCC DA0580. Actually, this study has revealed the presence of one specific protein presenting a quinone protein alcohol dehydrogenase-like domain [270]. Using a fluorescent tag, the protein was found to be targeted to the endoplasmic reticulum where it could be involved in the formation of oleosomes [256]. Transportation of oleosomes could occur by exocytosis as observed with the Chlorophyceae alga Dunaliella salina [271].

Formation and composition of oleosomes is of course of particular interest in the context of lipid production because they appear to be a vehicle for oozing (see Section 4). Hildebrand et al. [90] assumed that the larger the size of a diatom, the larger its lipid droplets. This expectation was not confirmed by our measurements as no correlation was found between biovolume and total lipid droplet volume within a cell (Figure 4B,C) and biovolume category \#1 in this study had the largest visible oil contents (Figure 4C). This lack of correlation extends even to individual diatoms in chains, which can be presumed to be clonal (Manoylov, unpublished observations, cf. [109]), i.e., genetically identical, and to have experienced the same microenvironment. Time lapse observations of lipid droplets in unicellular and colonial diatoms might help understand these variations and may be important for elucidating the optimal conditions for oil production, and for recovering oil synthesis after mechanical milking $c f$. [272-279].

\section{Conclusions and Perspectives}

The study of HVM from microalgae is still in its infancy [204]. Microalgae are fast growing, common, and readily available. The commercial exploitation of microalgae to produce HVM is not new but so far is a niche market because these HVM have no crucial importance for human society. For instance, the ambition to replace a significant part, if not all, of the fossil oil consumption by lipids produced by microalgae, not only constitutes a change of paradigm but also a tremendous change in the market, and consequently, in production. To maximize the benefits of this possibility, it is desirable 
to have environmentally benign production processes. We have reviewed alternative possibilities to reach this goal via milking of diatoms and illustrated them with original data.

At the time of writing, crude oil prices have dipped, perhaps due to economics [280,281], market manipulation [282], or increased production due to fracking [283,284]. In the short term this volatility is hard on biofuel startups [285], whose cost per US gallon presently varies from $\$ 9$ to $\$ 40$ [286]. Nevertheless, we anticipate that in the long run biofuels, perhaps obtained via diatom milking, could technologically fit smoothly into our present transportation and energy sectors, maybe at lower cost, while indeed disrupting many current economic and geopolitical arrangements [287]. The ongoing debate over global warming/climate change, including astronomical phenomena [288-290], serves as a backdrop, providing breathing room [291] or a sense of urgency [292] or despondency [293], depending on which working hypotheses one adopts for human versus cosmic impact. The very act of working on the science of biofuel production puts scientists directly into a position to influence policy [294,295]. Milking approaches to biofuels may alter their economics, increasing their presently low [296] EROI (energy return on investment). One hour of sunshine falling on Earth is equivalent to a year's worth of human energy consumption, so there is plenty of room for maneuvering, including the prospect of achieving artificial photosynthesis [297,298]. Perhaps we shall someday milk artificial diatoms.

To date, the Chlorophyta algae have been the subjects of most biofuel research. Genera such as Chlorella, Botryococcus, Scenedesmus, Neochloris, and Chlamydomonas are the typically researched organisms. Research using Scenedesmus obliquus has yielded phenomenal increases of oil by manipulating chemical and physical factors. For instance, Mandal and Mallick [299] were able to increase the oil content by $43 \%$ ( $c f$. [179]). Algal fuels based on diatoms are beginning to show promise [27,90,157,158,176,300,301], which is reasonable, given their contribution to natural oil deposits [59]. Thus diatoms have the ability to produce large amounts of oil. For example, planktonic diatoms are reported to produce lipids in quantities up to $40 \%$ dry cell weight [302]. Cultured marine diatoms had $30 \%-45 \%$ dry weight as lipids [303]. The amount of oil in a single diatom is reported as up to $25 \%$ of the algal biomass [90] and could perhaps reach $60 \%$ of the nonsilica diatom dry mass [27]. For some diatom species, the amount of oil that could be produced has been projected to reach up to 200 times more oil per hectare than soybeans (reviewed in [27]). Diatoms also have the ability to reproduce quickly and can create very large biovolumes. Diatoms can reproduce and double in as little as five hours under laboratory conditions, and in as little as two days in the environment [27]. How fast milked, stationary diatom cultures will replace their oil is as yet untested.

There is no "puzzling underrepresentation of diatoms in the microalgal biofuels arena" [90], as they have been a focus since 1978 [204]. Biodiesel from microalgae or third generation renewable biofuels could meet the demand $[55,56]$ because they are projected to be capable of generating up to 6-200 times more crude oil per surface area than higher plants $[27,57,58] . \mathrm{CO}_{2}$ will be available either from the atmosphere or directly from industries. However, our calculations here indicate that there is not enough industrial $\mathrm{CO}_{2}$ waste to convert to biofuel to replace fossil energies used for transport.

Unlike crops like rice, wheat, corn, or sugarcane, which when used for ethanol biodiesels compete with food production, algae can be grown without impacting food production [166]. Algae also have other advantages: (a) algae can be cultivated on non-arable land; (b) they can use non-potable water such as municipal/agricultural waste, which also helps to bioremediate the water [20-24,76,165,197,297,304-308]; and (c) they produce a high per-acre yield [189,303,304]. 
In a recent technico-economic analysis of alga-derived biofuel under both technical and economic uncertainties associated with the development of biorefinery processes, Brownbridge et al. [309] concluded that it is unlikely that algal biodiesel as a primary product can be commercially feasible unless other HVM products are also extracted as exemplified by the new mobile algae refinery [310]. However, it is a well-known engineering dictum that it is difficult to maximize more than one function simultaneously without compromise [311]. Therefore, a better approach is to concentrate on optimizing one function only: for instance, milking diatoms or other algae for biofuel production. Microalga HVM come from the cellular process of photosynthesis and carbon metabolism. Many basic questions about microalgae, such as how the complex, interconnecting metabolic and regulation networks work, are as yet still unanswered. Getting this information requires not only genomic and transcriptomic analyses, but also more integrated omics analyses [236].

\section{Acknowledgments}

V.V. would like to thank Department of Biotechnology, Ministry of Science and Technology, Government of India for the financial support. K.M. would like to express gratitude to the many students measuring biovolumes and lipid droplets in her lab. R.G. thanks the Gulf Specimen Aquarium \& Marine Laboratory and Birds Hill Provincial Park for congenial natural environments for writing. B.S., J.M., H.G. thank the University of Le Mans for their financial support. H.G. thanks the "Le Mans Métropole" and "Le Conseil Général de la Sarthe" for funding her PhD research. V.B., G.P. and J.H. thank the University of Le Mans and the Mayenne Council for financial support.

\section{Author Contributions}

Conceived and designed the manuscript: R.G., B.S. Performed the experiments: K.M.M. Analyzed the data: K.M.M. Wrote the paper: V.V., K.M.M, H.G., V.B., J.H., G.P., J.M., R.G., B.S.

\section{Abbreviations}

DW: dry weight; EPA: Eicosapentaenoic acid; EROI: energy return on investment; FAE: Fatty Acid Ester-type; FT-IR: Fast-Fourier InfraRed spectroscopy; HVM: high value molecules; LED: light emitting diode; PBR: photobioreactor; PDMS: polydimethylsiloxane; PEF: pulsed electric field; PUFA: PolyUnsaturated Fatty Acids; SE: standard error; UVC: ultraviolet C band, TAG: TriAcylGlycerol.

\section{Supplementary Information}

Supplementary Table S1: Diatom taxa reported per site with samples from 10 different locations in Georgia.

Supplementary Data S2: Measurement of lipid droplets.

\section{Conflicts of Interest}

The authors declare no conflict of interest. 


\section{References}

1. Alexandratos, N.; Bruinsma, J. World Agriculture towards 2030/2050: The 2012 Revision; ESA Working paper Rome, FAO: Rome, Italy, 2012.

2. Mimouni, V.; Ulmann, L.; Pasquet, V.; Mathieu, M.; Picot, L.; Bougaran, G.; Cadoret, J.-P.; Morant-Manceau, A.; Schoefs, B. The potential of microalgae for the production of bioactive molecules of pharmaceutical interest. Curr. Pharm. Biotechnol. 2012, 13, 2733-2750.

3. Schoefs, B. Chlorophyll and carotenoid analysis in food products. A practical case-by-case view. TrAC Trends Anal. Chem. 2003, 22, 335-339.

4. Plaza, M.; Herrero, M.; Cifuentes, A.; Ibanez, E. Innovative natural functional ingredients from microalgae. J. Agric. Food Chem. 2009, 57, 7159-7170.

5. Chisti, Y. Biodiesel from microalgae beats bioethanol. Trends Biotechnol. 2008, 26, 126-131.

6. Drum, R.W.; Gordon, R. Star Trek replicators and diatom nanotechnology. Trends Biotechnol. 2003, 21, 325-328.

7. Gordon, R.; Sterrenburg, F.A.S.; Sandhage, K. A Special Issue on Diatom Nanotechnology. J. Nanosci. Nanotechnol. 2005, 5, 1-4.

8. Gordon, R.; Losic, D.; Tiffany, M.A.; Nagy, S.S.; Sterrenburg, F.A.S. The Glass Menagerie: Diatoms for novel applications in nanotechnology. Trends Biotechnol. 2009, 27, 116-127.

9. Gordon, R. Diatoms and nanotechnology: Early history and imagined future as seen through patents. In The Diatoms: Applications for the Environmental and Earth Sciences; Smol, J.P., Stoermer, E.F., Eds.; Cambridge University Press: Cambridge, UK, 2010; Volume 2, pp. 585-602.

10. Gordon, R.; Seckbach, J. The Science of Algal Fuels: Phycology, Geology, Biophotonics, Genomics and Nanotechnology; Springer: Dordrecht, The Netherlands, 2012.

11. Field, C.B.; Behrenfeld, M.J.; Randerson, J.T.; Falkowski, P. Primary production of the biosphere: Integrating terrestrial and oceanic components. Science 1998, 281, 237-240.

12. Williams, P.J.le B.; Laurens, L.M.L. Microalgae as biodiesel \& biomass feedstocks: Review \& analysis of the biochemistry, energetics \& economics. Energy Environ. Sci. 2010, 3, 554-590.

13. Lemoine, Y.; Schoefs, B. Secondary ketocarotenoid astaxanthin biosynthesis in algae: A multifunctional response to stress. Photosynth. Res. 2010, 106, 155-177.

14. Heydarizadeh, P.; Poirier, I.; Loizeau, D.; Ulmann, L.; Mimouni, V.; Schoefs, B.; Bertrand, M. Plastids of marine phytoplankton produce bioactive pigments and lipids. Mar. Drugs 2013, 11, 3425-3471.

15. Spolaore, P.; Joannis-Cassan, C.; Duran, E.; Isambert, A. Commercial applications of microalgae. J. Biosci. Bioeng. 2006, 101, 87-96.

16. Leu, S.; Boussiba, S. Advances in the production of high-value products by microalgae. Ind. Biotechnol. 2014, 10, 169-183.

17. Priyadarshani, I.; Rath, B. Commercial and industrial applications of micro algae-A review. J. Algal Biomass Util. 2012, 3, 89-100.

18. Henrikson, R.; Edwards, M. Imagine Our Algae Future: Visionary Algae Architecture and Landscape Designs: International Algae Competition; CreateSpace Independent Publishing Platform: Seattle, WA, USA, 2012. 
19. Henrikson, R.; Edwards, M. Algae Microfarms: For Home, School, Community and Urban Gardens, Rooftop, Mobile and Vertical Farms and Living Buildings; CreateSpace Independent Publishing Platform: Seattle, WA, USA, 2013.

20. Oswald, W.J. Micro-algae and waste-water treatment. In Micro-Algal Biotechnology; Borowitzka, M.A., Borowitzka, L.J., Eds.; Cambridge University Press: New York, NY, USA, 1988; pp. 305-328.

21. Oswald, W.J. The role of microalgae in liquid waste treatment and reclamation. In Algae and Human Affairs; Lembi, C.A., Waaland, J.R., Eds.; Cambridge University Press: Cambridge, UK, 1988; pp. 255-281.

22. De la Noüe, J.; Laliberté, G.; Proulx, D. Algae and wastewater. J. Appl. Phycol. 1992, 4, $247-254$.

23. Shilton, A.N.; Powell, N.; Guieysse, B. Plant based phosphorus recovery from wastewater via algae and macrophytes. Curr. Opin. Biotechnol. 2012, 23, 884-889.

24. Ramachandra, T.V.; Madhab, M.D.; Shilpi, S.; Joshi, N.V. Algal biofuel from urban wastewater in India: Scope and challenges. Renew. Sust. Energ. Rev. 2013, 21, 767-777.

25. Koussa, J.; Chaiboonchoe, A.; Salehi-Ashtiani, K. Computational approaches for microalgal biofuel optimization: A review. BioMed Res. Int. 2014, 2014, 649453.

26. Levitan, O.; Dinamarca, J.; Hochman, G.; Falkowski, P.G. Diatoms: A fossil fuel of the future. Trends Biotechnol. 2014, 32, 117-124.

27. Ramachandra, T.V.; Mahapatra, D.M.; Karthick, B.; Gordon, R. Milking diatoms for sustainable energy: Biochemical engineering versus gasoline-secreting diatom solar panels. Ind. Eng. Chem. Res. 2009, 48, 8769-8788.

28. Metting, F.B., Jr.; Rayburn, W.R.; Reynaud, P.A. Algae and agriculture. In Algae and Human Affairs; Lembi, C.A., Waaland, J.R., Eds.; Cambridge University Press: Cambridge, UK, 1988; pp. 335-370.

29. Li, S.; Glombitza, K.W.; Koch, M. Phlorotannins from the brown alga Carpophyllum maschalocarpum. Planta Med. 1989, 55, 610-611.

30. Rengasamy, K.R.R.; Kulkarni, M.G.; Stirk, W.A.; van Staden, J. Advances in algal drug research with emphasis on enzyme inhibitors. Biotechnol. Adv. 2014, 32, 1364-1381.

31. Becker, E.W. Nutritional properties of microalgae: Potentials and constraints. In CRC Handbook of Microalgal Mass Culture; Richmond, A., Ed.; CRC Press: Boca Raton, FL, USA, 1986; pp. 339-419.

32. Klok, A.J.; Lamers, P.P.; Martens, D.E.; Draaisma, R.B.; Wijffels, R.H. Edible oils from microalgae: Insights in TAG accumulation. Trends Biotechnol. 2014, 32, 521-528.

33. Lane, K.; Derbyshire, E.; Li, W.; Brennan, C. Bioavailability and potential uses of vegetarian sources of omega-3 fatty acids: A review of the literature. Crit. Rev. Food Sci. Nutr. 2014, 54, $572-579$.

34. De Pauw, N.; Persoone, G. Micro-algae for aquaculture. In Micro-Algal Biotechnology; Borowitzka, M.A., Borowitzka, L.J., Eds.; Cambridge University Press: New York, NY, USA, 1988; pp. 197-221.

35. Benemann, J.R. Microalgae aquaculture feeds. J. Appl. Phycol. 1992, 4, 233-245.

36. Becker, E.W. Micro-algae as a source of protein. Biotechnol. Adv. 2007, 25, 207-210. 
37. Hawkins, R.L.; Nakamura, M. Expression of human growth hormone by the eukaryotic alga, Chlorella. Curr. Microbiol. 1999, 38, 335-341.

38. Gregory, J.A.; Mayfield, S.P. Developing inexpensive malaria vaccines from plants and algae. Appl. Microbiol. Biotechnol. 2014, 98, 1983-1990.

39. Rosales-Mendoza, S. Future directions for the development of Chlamydomonas-based vaccines. Expert Rev. Vaccines 2013, 12, 1011-1019.

40. Pérez-López, P.; González-García, S.; Ulloa, R.G.; Sineiro, J.; Feijoo, G.; Teresa Moreira, M. Life cycle assessment of the production of bioactive compounds from Tetraselmis suecica at pilot scale. J. Cleaner Prod. 2014, 64, 323-331.

41. Moulin, P.; Lemoine, Y.; Schoefs, B. Modifications of the carotenoid metabolism in plastids: A response to stress conditions. In Handbook of Plant and Crop Stress, 3rd ed.; Pessarakli, M., Ed.; CRC Press: Boca Raton, FL, USA, 2010; pp. 407-433.

42. Li, Y.; Horsman, M.; Wu, N.; Lan, C.Q.; Dubois-Calero, N. Biofuels from microalgae. Biotechnol. Prog. 2008, 24, 815-820.

43. Garibay-Hernández, A.; Vazquez-Duhalt, R.; Serrano-Carreón, L.; Martinez, A. Nitrogen limitation in Neochloris oleoabundans: A reassessment of its effect on cell growth and biochemical composition. Appl. Biochem. Biotechnol. 2013, 171, 1775-1791.

44. Ge, Y.; Liu, J.; Tian, G. Growth characteristics of Botryococcus braunii 765 under high $\mathrm{CO}_{2}$ concentration in photobioreactor. Bioresour. Technol. 2011, 102, 130-134.

45. Illman, A.M.; Scragg, A.H.; Shales, S.W. Increase in Chlorella strains calorific values when grown in low nitrogen medium. Enzyme Microb. Technol. 2000, 27, 631-635.

46. Scragg, A.H.; Illman, A.M.; Carden, A.; Shales, S.W. Growth of microalgae with increased calorific values in a tubular bioreactor. Biomass Bioenergy 2002, 23, 67-73.

47. Liang, Y.; Sarkany, N.; Cui, Y. Biomass and lipid productivities of Chlorella vulgaris under autotrophic, heterotrophic and mixotrophic growth conditions. Biotechnol. Lett. 2009, 31, 1043-1049.

48. Li, Z.; Yuan, H.; Yang, J.; Li, B. Optimization of the biomass production of oil algae Chlorella minutissima UTEX2341. Bioresour. Technol. 2011, 102, 9128-9134.

49. Wen, Z.Y.; Chen, F. Heterotrophic production of eicosapentaenoic acid by microalgae. Biotechnol. Adv. 2003, 21, 273-294.

50. Bromke, M.A.; Giavalisco, P.; Willmitzer, L.; Hesse, H. Metabolic analysis of adaptation to short-term changes in culture conditions of the marine diatom Thalassiosira pseudonana. PLoS ONE 2013, 8, e67340.

51. Ethier, S.; Woisard, K.; Vaughan, D.; Wen, Z. Continuous culture of the microalgae Schizochytrium limacinum on biodiesel-derived crude glycerol for producing docosahexaenoic acid. Bioresour. Technol. 2011, 102, 88-93.

52. Deschamps, P.; Guillebeault, D.; Devassine, J.; Dauvillée, D.; Haebel, S.; Steup, M.; Buléon, A.; Putaux, J.-L.; Slomianny, M.-C.; Colleoni, C.; et al. The heterotrophic dinoflagellate Crypthecodinium cohnii defines a model genetic system to investigate cytoplasmic starch synthesis. Eukaryot. Cell 2008, 7, 872-880.

53. Sharma, K.K.; Schuhmann, H.; Schenk, P.M. High lipid induction in microalgae for biodiesel production. Energies 2012, 5, 1532-1553. 
54. Pal, D.; Khozin-Goldberg, I.; Cohen, Z.; Boussiba, S. The effect of light, salinity, and nitrogen availability on lipid production by Nannochloropsis sp. Appl. Microbiol. Biotechnol. 2011, 90, 1429-1441.

55. Cadoret, J.-P.; Bernard, O. La production de biocarburant lipidique avec des microalgues: Promesses et defis/Lipid biofuel production with microalgae: Potential and challenges. J. Soc. Biol. 2008, 202, 201-211.

56. Chisti, Y. Biodiesel from microalgae. Biotechnol. Adv. 2007, 25, 294-306.

57. Hu, Q.; Sommerfeld, M.; Jarvis, E.; Ghirardi, M.; Posewitz, M.; Seibert, M.; Darzins, A. Microalgal triacylglycerols as feedstocks for biofuel production: Perspectives and advances. Plant J. 2008, 54, 621-639.

58. Demirbas, A. Progress and recent trends in biodiesel fuels. Energy Conv. Manag. 2009, 50, 14-34.

59. Shukla, S.K.; Mohan, R. The contribution of diatoms to worldwide crude oil deposits. In The Science of Algal Fuels: Phycology, Geology, Biophotonics, Genomics and Nanotechnology; Gordon, R., Seckbach, J., Eds.; Springer: Dordrecht, The Netherlands, 2012; pp. 355-382.

60. Smetacek, V. Diatoms and the ocean carbon cycle. Protist 1999, 150, 25-32.

61. Wu, Y.; Campbell, D.A.; Irwin, A.J.; Suggett, D.J.; Finkel, Z.V. Ocean acidification enhances the growth rate of larger diatoms. Limnol. Oceanogr. 2014, 59, 1027-1034.

62. Hejazi, M.A.; Wijffels, R.H. Milking of microalgae. Trends Biotechnol. 2004, 22, 189-194.

63. Orosa, M.; Franqueira, D.; Cid, A.; Abalde, J. Analysis and enhancement of astaxanthin accumulation in Haematococcus pluvialis. Bioresour. Technol. 2005, 96, 373-378.

64. Kamath, B.S.; Vidhyavathi, R.; Sarada, R.; Ravishankar, G.A. Enhancement of carotenoids by mutation and stress induced carotenogenic genes in Haematococcus pluvialis mutants. Bioresour. Technol. 2008, 99, 8667-8673.

65. Bahadar, A.; Khan, M.B. Progress in energy from microalgae: A review. Renew. Sust. Energy Rev. 2013, 27, 128-148.

66. Greenwell, H.C.; Laurens, L.M.L.; Shields, R.J.; Lovitt, R.W.; Flynn, K.J. Placing microalgae on the biofuels priority list: A review of the technological challenges. J. R. Soc. Interface 2010, 7 , $703-726$.

67. Zhang, F.; Cheng, L.H.; Xu, X.H.; Zhang, L.; Chen, H.L. Screening of biocompatible organic solvents for enhancement of lipid milking from Nannochloropsis sp. Process Biochem. 2011, 46, 1934-1941.

68. Mercer, P.; Armenta, R.E. Developments in oil extraction from microalgae. Eur. J. Lipid Sci. Technol. 2011, 113, 539-547.

69. Benemann, J.R.; Weissman, J.C.; Koopman, B.L.; Oswald, W.J. Energy production by microbial photosynthesis. Nature 1977, 268, 19-23.

70. De Boer, K.; Moheimani, N.R.; Borowitzka, M.A.; Bahri, P.A. Extraction and conversion pathways for microalgae to biodiesel: A review focused on energy consumption. J. Appl. Phycol. 2012, 24, 1681-1698.

71. Montagne, X.; Porot, P.; Aymard, C.; Querleu, C.; Bouter, A.; Lorne, D.; Cadoret, J.-P.; Lombaert-Valot, I.; Petillon, O. Algogroup: Towards a shared vision of the possible deployment of algae to biofuels. Oil Gas Sci. Technol. 2013, 68, 875-898. 
72. Ahmed, F.; Li, Y.; Schenk, P.M. Algal biorefinery: Sustainable production of biofuels and aquaculture feed? In The Science of Algal Fuels: Phycology, Geology, Biophotonics, Genomics and Nanotechnology; Gordon, R., Seckbach, J., Eds.; Springer: Dordrecht, The Netherlands, 2012; pp. 21-42.

73. Bajhaiya, A.K.; Suseela, M.R.; Ramteka, P.W. Approaches and prospectives for algal fuel. In The Science of Algal Fuels: Phycology, Geology, Biophotonics, Genomics and Nanotechnology; Gordon, R., Seckbach, J., Eds.; Springer: Dordrecht, The Netherlands, 2012; pp. 269-282.

74. Pattarkine, M.; Pattarkine, V.M. Nanotechnology for algal biofuels. In The Science of Algal Fuels: Phycology, Geology, Biophotonics, Genomics and Nanotechnology; Gordon, R., Seckbach, J., Eds.; Springer: Dordrecht, The Netherlands, 2012; pp. 147-164.

75. Riosmena-Rodríguez, R.; Arredondo-Vega, B.O.; Reynoso-Granados, T.; Cordoba, M.; López-Vivas, J.M.; López-Calderon, J.M. Approaches to and perspectives on biodiesel and oil production using algae in Mexico. In The Science of Algal Fuels: Phycology, Geology, Biophotonics, Genomics and Nanotechnology; Gordon, R., Seckbach, J., Eds.; Springer: Dordrecht, The Netherlands, 2012; pp. 269-282.

76. Craggs, R.J.; Lundquist, T.; Benemann, J. Wastewater treatment pond algal production for biofuel. In The Science of Algal Fuels: Phycology, Geology, Biophotonics, Genomics and Nanotechnology; Gordon, R., Seckbach, J., Eds.; Springer: Dordrecht, The Netherlands, 2012; pp. 425-446.

77. Kumar, S. Sub-and supercritical water based processes for microalgae to biofuels. In The Science of Algal Fuels: Phycology, Geology, Biophotonics, Genomics and Nanotechnology; Gordon, R., Seckbach, J., Eds.; Springer: Dordrecht, The Netherlands, 2012; pp. 467-494.

78. Richardson, J.W.; Johnson, M.D.; Outlaw, J.L. Economic comparison of open pond raceways to photo bio-reactors for profitable production of algae for transportation fuels in the Southwest. Algal Res. Biomass Biofuels Bioprod. 2012, 1, 93-100.

79. Lane, J. Joule's quest for fuels from $\mathrm{CO}_{2}$, sunlight and water. Available online: http://www. biofuelsdigest.com/bdigest/2014/07/03/joules-quest-for-fuels-from-co2-sunlight-and-water/ (accessed on 21 April 2015).

80. Wilkinson, S. Curb global warming: Make waste $\mathrm{CO}_{2}$ into fuel. Chem. Eng. News 1997, 75, 6 .

81. Jiang, Z.; Xiao, T.; Kuznetsov, V.L.; Edwards, P.P. Turning carbon dioxide into fuel. Phil. Trans. R. Soc. Lond. A: Math. Phys. Eng. Sci. 2010, 368, 3343-3364.

82. Ladd, C.; Venter, J.C. 10 Big Questions for Maverick Geneticist J. Craig Venter on America's Energy Future. Available online: http://www.popularmechanics.com/blogs/science_news/ 4275738.html (accessed on 8 August 2010).

83. Wang, X.W.; Liang, J.R.; Luo, C.S.; Chen, C.P.; Gao, Y.H. Biomass, total lipid production, and fatty acid composition of the marine diatom Chaetoceros muelleri in response to different $\mathrm{CO}_{2}$ levels. Bioresour. Technol. 2014, 161, 124-130.

84. Van der Hoeven, M. CO $\mathrm{C}_{2}$ Emissions from Fuel Combustion: Highlights, 2013 ed.; International Energy Agency: Paris, France, 2013.

85. Moheimani, N. Microalgae Culture (3); Algae R\&D Center, Murdoch University: Perth, Australia, 2014. 
86. Frenz, J.; Largeau, C.; Casadevall, E. Hydrocarbon recovery by extraction with a biocompatible solvent from free and immobilized cultures of Botryococcus braunii. Enzyme Microb. Technol. 1989, 11, 717-724.

87. Zhang, F.; Cheng, L.-H.; Xu, X.-H.; Zhang, L.; Chen, H.-L. Application of membrane dispersion for enhanced lipid milking from Botryococcus braunii FACHB 357. J. Biotechnol. 2013, 165, 22-29.

88. Rickman, M.; Davis, R.H.; Pellegrino, J. Fractionation of organic fuel precursors from electrolytes with membranes. Ind. Eng. Chem. Res. 2013, 52, 10530-10539.

89. Yadugiri, V.T. Milking diatoms-A new route to sustainable energy. Curr. Sci. 2009, 97, $748-750$.

90. Hildebrand, M.; Davis, A.K.; Smith, S.R.; Traller, J.C.; Abbriano, R. The place of diatoms in the biofuels industry. Biofuels 2012, 3, 221-240.

91. Ho, S.-H.; Ye, X.; Hasunuma, T.; Chang, J.-S.; Kondo, A. Perspectives on engineering strategies for improving biofuel production from microalgae-A critical review. Biotechnol. Adv. 2014, 32, 1448-1459.

92. Ciesielski, A.; Limited, R.T. An Introduction to Rubber Technology; Rapra Technology Limited: Shrewsbury, UK, 1999.

93. Svanberg, I.; Sõukand, R.; Łuczaj, Ł.; Kalle, R.; Zyryanova, O.; Dénes, A.; Papp, N.; Nedelcheva, A.; Šeškauskaite, D.; Kołodziejska-Degórska, I.; et al. Uses of tree saps in northern and eastern parts of Europe. Acta Soc. Bot. Pol. 2012, 81, 343-357.

94. Nearing, H.; Nearing, S. The Maple Sugar Book: Together with Remarks on Pioneering as a Way of Living in the Twentieth Century; Chelsea Green Publishing: White River Junction, VT, USA, 2000.

95. Munson, P.J. Still more on the antiquity of maple sugar and syrup in aboriginal eastern North America. J. Ethnobiol. 1989, 9, 159-170.

96. Haller, J.S., Jr. Sampson of the terebinthinates: Medical history of turpentine. South. Med. J. 1984, 77, 750-754.

97. Sauer, T.; Galinski, E.A. Bacterial milking: A novel bioprocess for production of compatible solutes. Biotechnol. Bioeng. 1998, 57, 306-313.

98. Van-Thuoc, D.; Guzmán, H.; Quillaguamán, J.; Hatti-Kaul, R. High productivity of ectoines by Halomonas boliviensis using a combined two-step fed-batch culture and milking process. J. Biotechnol. 2010, 147, 46-51.

99. Gillet, J.-N. Ultrafast molecular dynamics of biofuel extraction for microalgae and bacteria milking: Blocking membrane folding pathways to damaged lipid-bilayer conformations with nanomicelles. J. Biomol. Struct. Dyn. 2015, 33, 690-705.

100. Zhang, F.; Cheng, L.H.; Xu, X.H.; Zhang, L.; Chen, H.L. Technologies of microalgal harvesting and lipid extraction. Prog. Chem. 2012, 24, 2062-2072.

101. Wijffels, R.H.; Barbosa, M.J. An outlook on microalgal biofuels. Science 2010, 329, 796-799.

102. Ghasemi Naghdi, F.; Thomas-Hall, S.R.; Durairatnam, R.; Pratt, S.; Schenk, P.M. Comparative effects of biomass pre-treatments for direct and indirect transesterification to enhance microalgal lipid recovery. Front. Energy Res. 2014, 2, 57. 
103. Ganeva, V.; Galutzov, B.; Teissie, J. High yield electroextraction of proteins from yeast by a flow process. Anal. Biochem. 2003, 315, 77-84.

104. Coustets, M.; Al-Karablieh, N.; Thomsen, C.; Teissie, J. Flow process for electroextraction of total proteins from microalgae. J. Membr. Biol. 2013, 246, 751-760.

105. Coustets, M.; Joubert-Durigneux, V.; Hérault, J.; Schoefs, B.; Blanckaert, V.; Garnier, J.-P.; Teissié, J. Optimization of protein electroextraction from microalgae by a flow process. Bioelectrochemistry 2015, 103, 74-81.

106. Reep, P.; Green, M.P. Procedure for extracting of lipids from algae without cell sacrifice. US Patent 20120040428 A1, 16 February 2012.

107. Gateau, H.; Marchand, J.; Schoefs, B. Pulse electric fields allow the biocompatible extraction of molecules from the microalgae Haematococcus pluvialis. In Abstracts, Functional Studies on Model Organisms (EFOR), 6th Annual Meeting, Paris, France; EFOR: Paris, France, 2015.

108. Sheng, J.; Vannela, R.; Rittmann, B.E. Evaluation of cell-disruption effects of pulsed-electric-field treatment of Synechocystis PCC 6803. Environ. Sci. Technol. 2011, 45, 3795-3802.

109. Vinayak, V.; Gordon, R.; Gautam, S.; Rai, A. Discovery of a diatom that oozes oil. Adv. Sci. Lett. 2014, 20, 1256-1267.

110. Tsukagoshi, N.; Yoshida, H.; Katsurayama, M.; Udaka, S. Uncoupled release of protein and lipid in a protein-secreting bacterium, Bacillus brevis-47. Biochim. Biophys. Acta 1983, 759, 278-285.

111. Raetz, C.R.H. Biosynthesis, secretion and function of lipid A in Gram-negative bacteria. Glycobiology 2001, 11, 872-872.

112. Wald, M.L. Biotech Company to Patent Fuel-Secreting Bacterium. Available online: http://www. nytimes.com/2010/09/14/science/earth/14fuel.html (accessed on 21 April 2015).

113. Liu, X.; Sheng, J.; Curtiss, R., III. Fatty acid production in genetically modified cyanobacteria. Proc. Natl. Acad. Sci. USA 2011, 108, 6899-6904.

114. MB-BigB Joule Unlimited's bacteria secretes diesel fuel. Available online: http://www.alt-energy. info/biofuel/joule-unlimiteds-bacteria-secretes-diesel-fuel/ (accessed on 29 August 2012).

115. Robertson, D.E.; Jacobson, S.A.; Morgan, F.; Berry, D.; Church, G.M.; Afeyan, N.B. A new dawn for industrial photosynthesis. Photosynth. Res. 2011, 107, 269-277.

116. Araujo, G.S.; Matos, L.J.; Fernandes, J.O.; Cartaxo, S.J.; Goncalves, L.R.; Fernandes, F.A.; Farias, W.R. Extraction of lipids from microalgae by ultrasound application: Prospection of the optimal extraction method. Ultrason. Sonochem. 2013, 20, 95-98.

117. Ranjan, A.; Patil, C.; Moholkar, V.S. Mechanistic assessment of microalgal lipid extraction. Ind. Eng. Chem. Res. 2010, 49, 2979-2985.

118. Rajasekhar, P.; Fan, L.; Thang, N.; Roddick, F.A. Impact of sonication at $20 \mathrm{kHz}$ on Microcystis aeruginosa, Anabaena circinalis and Chlorella sp. Water Res. 2012, 46, 1473-1481.

119. Joyce, E.M.; King, P.M.; Mason, T.J. The effect of ultrasound on the growth and viability of microalgae cells. J. Appl. Phycol. 2014, 26, 1741-1748.

120. Broekman, S.; Pohlmann, O.; Beardwood, E.S.; de Meulenaer, E.C. Ultrasonic treatment for microbiological control of water systems. Ultrason. Sonochem. 2010, 17, 1041-1048.

121. Doshi, R.; Tuan, N.; Chang, G. Transporter-mediated biofuel secretion. Proc. Natl. Acad. Sci. USA 2013, 110, 7642-7647. 
122. Dunlop, M.J.; Dossani, Z.Y.; Szmidt, H.L.; Chu, H.C.; Lee, T.S.; Keasling, J.D.; Hadi, M.Z.; Mukhopadhyay, A. Engineering microbial biofuel tolerance and export using efflux pumps. Mol. Syst. Biol. 2011, 7, 487.

123. Dunahay, T.G.; Jarvis, E.E.; Zeiler, K.G.; Roessler, P.G.; Brown, L.M. Genetic engineering of microalgae for fuel production: Scientific note. Appl. Biochem. Biotechnol. 1992, 34-5, 331-339.

124. Coll, J.M. Methodologies for transferring DNA into eukaryotic microalgae. Span. J. Agric. Res. 2006, 4, 316-330.

125. León, R.; Fernández, E. Nuclear transformation of eukaryotic microalgae: Historical overview, achievements and problems. Adv. Exp. Med. Biol. 2007, 616, 1-11.

126. Miyahara, M.; Aoi, M.; Inoue-Kashino, N.; Kashino, Y.; Ifuku, K. Highly efficient transformation of the diatom Phaeodactylum tricornutum by multi-pulse electroporation. Biosci. Biotechnol. Biochem. 2013, 77, 874-876.

127. Li, F.J.; Gao, D.W.; Hu, H.H. High-Efficiency nuclear transformation of the oleaginous marine Nannochloropsis species using PCR product. Biosci. Biotechnol. Biochem. 2014, 78, 812-817.

128. Zhang, C.Y.; Hu, H.H. High-efficiency nuclear transformation of the diatom Phaeodactylum tricornutum by electroporation. Mar. Genom. 2014, 16, 63-66.

129. Stirke, A.; Zimkus, A.; Balevicius, S.; Stankevic, V.; Ramanaviciene, A.; Ramanavicius, A.; Zurauskiene, N. Permeabilization of yeast Saccharomyces cerevisiae cell walls using nanosecond high power electrical pulses. Appl. Phys. Lett. 2014, 105, 253701.

130. Joubert, V.; Cheype, C.; Bonnet, J.; Packan, D.; Garnier, J.-P.; Teissie, J.; Blanckaert, V. Inactivation of Bacillus subtilis var. niger of both spore and vegetative forms by means of corona discharges applied in water. Water Res. 2013, 47, 1381-1389.

131. Antezana Zbinden, M.D.; Sturm, B.S.M.; Nord, R.D.; Carey, W.J.; Moore, D.; Shinogle, H.; Stagg-Williams, S.M. Pulsed electric field (PEF) as an intensification pretreatment for greener solvent lipid extraction from microalgae. Biotechnol. Bioeng. 2013, 110, 1605-1615.

132. Deipolyi, A.R.; Golberg, A.; Yarmush, M.L.; Arellano, R.S.; Oklu, R. Irreversible electroporation: Evolution of a laboratory technique in interventional oncology. Diagn. Interv. Radiol. 2014, 20, 147-154.

133. Sixou, S.; Teissié, J. Specific electropermeabilization of leukocytes in a blood sample and application to large volumes of cells. Biochim. Biophys. Acta 1990, 1028, 154-160.

134. Bellard, E.; Teissié, J. Double-pulse approach of electrogenotherapy: An analysis at the single cell level. IEEE Trans. Plasma Sci. 2009, 37, 538-544.

135. Rols, M.P.; Teissie, J. Ionic-strength modulation of electrically induced permeabilization and associated fusion of mammalian cells. Eur. J. Biochem. 1989, 179, 109-115.

136. Liu, X.; Fallon, S.; Sheng, J.; Curtiss, R., III. CO2-limitation-inducible Green Recovery of fatty acids from cyanobacterial biomass. Proc. Natl. Acad. Sci. USA 2011, 108, 6905-6908.

137. Reppas, N.B.; Ridley, C.P. Methods and Compositions for the Recombinant Biosynthesis of $N$-Alkanes. United States Patent 7,794,969, 14 September 2010.

138. Ozkan, A.; Berberoglu, H. Physico-chemical surface properties of microalgae. Colloids Surf. $B$ Biointerfaces 2013, 112, 287-293.

139. Ruen-ngam, D.; Shotipruk, A.; Pavasant, P. Comparison of extraction methods for recovery of astaxanthin from Haematococcus pluvialis. Sep. Sci. Technol. 2010, 46, 64-70. 
140. Zou, T.-B.; Jia, Q.; Li, H.-W.; Wang, C.-X.; Wu, H.-F. Response surface methodology for ultrasound-assisted extraction of astaxanthin from Haematococcus pluvialis. Mar. Drugs 2013, $11,1644-1655$.

141. Kong, W.; Liu, N.; Zhang, J.; Yang, Q.; Hua, S.; Song, H.; Xia, C. Optimization of ultrasound-assisted extraction parameters of chlorophyll from Chlorella vulgaris residue after lipid separation using response surface methodology. J. Food Sci. Technol.-Mysore 2014, 51, 2006-2013.

142. Macias-Sánchez, M.D.; Mantell, C.; Rodríguez, M.; Martinez de la Ossa, E.; Lubián, L.M.; Montero, O. Comparison of supercritical fluid and ultrasound-assisted extraction of carotenoids and chlorophyll a from Dunaliella salina. Talanta 2009, 77, 948-952.

143. Pasquet, V.; Chérouvrier, J.-R.; Farhat, F.; Thiéry, V.; Piot, J.-M.; Bérard, J.-B.; Kaas, R.; Serive, B.; Patrice, T.; Cadoret, J.-P.; et al. Study on the microalgal pigments extraction process: Performance of microwave assisted extraction. Process Biochem. 2011, 46, 59-67.

144. Roselló-Soto, E.; Galanakis, C.M.; Brnčić, M.; Orlien, V.; Trujillo, F.J.; Mawson, R.; Knoerzer, K.; Tiwari, B.K.; Barba, F.J. Clean recovery of antioxidant compounds from plant foods, by-products and algae assisted by ultrasounds processing. Modeling approaches to optimize processing conditions. Trends Food Sci. Technol. 2015, 42, 134-149.

145. Sterrenburg, F.A.S.; Gordon, R.; Tiffany, M.A.; Nagy, S.S. Diatoms: Living in a constructal environment. In Algae and Cyanobacteria in Extreme Environments. Series: Cellular Origin, Life in Extreme Habitats and Astrobiology, Volume 11; Seckbach, J., Ed.; Springer: Dordrecht, The Netherlands, 2007; pp. 141-172.

146. Round, F.E.; Crawford, R.M.; Mann, D.G. The Diatoms, Biology \& Morphology of the Genera; Cambridge University Press: Cambridge, UK, 1990.

147. Stoermer, E.F.; Julius, M.L. Centric diatoms. In Freshwater Algae of North America. Ecology and Classification; Wehr, J.D., Sheath, R.G., Eds.; Academic Press: New York, NY, USA, 2003; pp. 559-594.

148. Bahulikar, R.A.; Kroth, P.G. Localization of EPS components secreted by freshwater diatoms using differential staining with fluorophore-conjugated lectins and other fluorochromes. Eur. J. Phycol. 2007, 42, 199-208.

149. Kociolek, J.P.; Stoermer, E.F. A preliminary investigation of the phylogenetic relationships among the freshwater, apical pore field-bearing cymbelloid and gomphonemoid diatoms (Bacillariophyceae). J. Phycol. 1988, 24, 377-385.

150. Hamm, C.E.; Merkel, R.; Springer, O.; Jurkojc, P.; Maier, C.; Prechtel, K.; Smetacek, V. Architecture and material properties of diatom shells provide effective mechanical protection. Nature 2003, 421, 841-843.

151. Abodeely, J.; Stevens, D.; Ray, A.; Schaller, K.; Newby, D. Algal Supply System Design-Harmonized Version [Report INL/EXT-13-28890]; Idaho National Laboratory (INL): Idaho Falls, ID, USA, 2013.

152. Anderson, E. A cytological study of the centrifuged whole, half, and quarter eggs of the sea urchin Arbacia punctulata. J. Cell Biol. 1970, 47, 711-733.

153. Furnas, M.J. Net in situ growth rates of phytoplankton in an oligotrophic, tropical shelf ecosystem. Limnol. Oceanogr. 1991, 36, 13-29. 
154. Ketheesan, B.; Nirmalakhandan, N. Development of a new airlift-driven raceway reactor for algal cultivation. Appl. Energy 2011, 88, 3370-3376.

155. Matsumoto, H.; Shioji, N.; Hamasaki, A.; Ikuta, Y. Basic study on optimization of raceway-type algal cultivator. J. Chem. Eng. Jpn. 1996, 29, 541-543.

156. Cohen, B. Changes Going on in the Algae Production Industry. Available online: http://www.nationalalgaeassociation.com/Changes_going_on_in_the_algae_production_industry. docx (accessed on 23 April 2015).

157. Day, J.G.; Stanley, M.S. Biological constraints on the production of microalgal-based biofuels. In The Science of Algal Fuels: Phycology, Geology, Biophotonics, Genomics and Nanotechnology; Gordon, R., Seckbach, J., Eds.; Springer: Dordrecht, The Netherlands, 2012; pp. 101-130.

158. McNichol, J.; McGinn, P. Adapting mass algaculture for a northern climate. In The Science of Algal Fuels: Phycology, Geology, Biophotonics, Genomics and Nanotechnology; Gordon, R., Seckbach, J., Eds.; Springer: Dordrecht, The Netherlands, 2012; pp. 131-146.

159. Rhodes, C.J. Making fuel from algae: Identifying fact amid fiction. In The Science of Algal Fuels: Phycology, Geology, Biophotonics, Genomics and Nanotechnology; Gordon, R., Seckbach, J., Eds.; Springer: Dordrecht, The Netherlands, 2012; pp. 177-192.

160. Bhargava, P.; Mohan, M.K. From isolation of potential microalgal strains to strain engineering for biofuel. In The Science of Algal Fuels: Phycology, Geology, Biophotonics, Genomics and Nanotechnology; Gordon, R., Seckbach, J., Eds.; Springer: Dordrecht, The Netherlands, 2012; pp. 63-82.

161. Zittelli, G.C.; Rodolfi, L.; Bassi, N.; Biondi, N.; Tredici, M.R. Photobioreactors for microalgal biofuel production. In Algae for Biofuels and Energy; Springer: Dordrecht, The Netherlands, 2013; pp. 115-131.

162. Schulze, P.S.C.; Barreira, L.A.; Pereira, H.G.C.; Perales, J.A.; Varela, J.C.S. Light emitting diodes (LEDs) applied to microalgal production. Trends Biotechnol. 2014, 32, 423-431.

163. Darko, E.; Heydarizadeh, P.; Schoefs, B.; Sabzalian, M.R. Photosynthesis under artificial light: The shift in primary and secondary metabolism. Philos. Trans. R. Soc. B Biol. Sci. 2014, 369, 20130243.

164. Reijnders, L. Foreword: The production of algal biofuels In The Science of Algal Fuels: Phycology, Geology, Biophotonics, Genomics and Nanotechnology; Gordon, R., Seckbach, J., Eds.; Springer: Dordrecht, The Netherlands, 2012; pp. xiii-xix.

165. Dahiya, A.; Todd, J.; McInnis, A. Wastewater treatment integrated with algae production for biofuel. In The Science of Algal Fuels: Phycology, Geology, Biophotonics, Genomics and Nanotechnology; Gordon, R., Seckbach, J., Eds.; Springer: Dordrecht, The Netherlands, 2012; pp. 447-466.

166. Gordon, R.; Poulin, B.J. Quitting cold turkey: Rapid oil independence for the USA. In The Science of Algal Fuels: Phycology, Geology, Biophotonics, Genomics and Nanotechnology; Gordon, R.; Seckbach, J., Eds.; Springer: Dordrecht, The Netherlands, 2012; pp. 3-20.

167. Wang, X.J.; Wang, X.B.; Gascoyne, P.R.C. General expressions for dielectrophoretic force and electrorotational torque derived using the Maxwell stress tensor method. J. Electrost. 1997, 39, 277-295. 
168. Beskok, Ali. Department of Mechanical Engineering, Southern Methodist University, Dallas, TX, USA. Personal communication, 2014.

169. Zhou, J.W.; Ellis, A.V.; Voelcker, N.H. Recent developments in PDMS surface modification for microfluidic devices. Electrophoresis 2010, 31, 2-16.

170. Forry, S.P.; Locascio, L.E. On-chip $\mathrm{CO}_{2}$ control for microfluidic cell culture. Lab Chip 2011, 11, 4041-4046.

171. Thorsen, T.; Maerkl, S.J.; Quake, S.R. Microfluidic large-scale integration. Science 2002, 298, 580-584.

172. Zhang, T.; Cui, T.H. Tunable wetting properties of patterned silicon microchannels with varied surface free energy based on layer-by-layer nano self-assembly. J. Micromech. Microeng. 2011, 21, 045015.

173. Lim, H.S.; Kim, J.Y.; Kwak, H.S.; Sim, S.J. Integrated microfluidic platform for multiple processes from microalgal culture to lipid extraction. Anal. Chem. 2014, 86, 8585-8592.

174. Jeffryes, C.; Campbell, J.; Li, H.Y.; Jiao, J.; Rorrer, G. The potential of diatom nanobiotechnology for applications in solar cells, batteries, and electroluminescent devices. Energy Environ. Sci. 2011, 4, 3930-3941.

175. Gordon, R.; Witkowski, A.; Gebeshuber, I.C.; Allen, C.S. The diatoms of Antarctica and their potential roles in nanotechnology. In Antarctica: Time of Change; Masó, M., Ed.; Editions ACTAR: Barcelona, Spain, 2010; pp. 84-95.

176. Chepurnov, V.A.; Chaerle, P.; Mann, D.G. How to breed diatoms: Examination of two species with contrasting reproductive biology. In The Science of Algal Fuels: Phycology, Geology, Biophotonics, Genomics and Nanotechnology; Gordon, R., Seckbach, J., Eds.; Springer: Dordrecht, The Netherlands, 2012; pp. 323-340.

177. Dodson, V.J.; Leblond, J.D. Now you see it, now you don't: Differences in hydrocarbon production in the diatom Phaeodactylum tricornutum due to growth temperature. J. Appl. Phycol. 2014, doi:10.1007/s 10811-014-0464-6.

178. Poulin, Bryan. Faculty of Business Administration, Lakehead University, Thunder Bay, Canada. Personal communication, 2014.

179. Mutanda, T.; Ramesh, D.; Karthikeyan, S.; Kumari, S.; Anandraj, A.; Bux, F. Bioprospecting for hyper-lipid producing microalgal strains for sustainable biofuel production. Bioresour. Technol. 2011, 102, 57-70.

180. Murphy, T.E. Artifcial Leaf for Biofuel Production and Harvesting: Transport Phenomena and Energy Conversion. Ph.D. Thesis, University of Texas: Austin, TX, USA, 2013.

181. Onay, M.; Sonmez, C.; Oktem, H.A.; Yucel, A.M. Thermo-resistant green microalgae for effective biodiesel production: Isolation and characterization of unialgal species from geothermal flora of Central Anatolia. Bioresour. Technol. 2014, 169, 62-71.

182. Nikulina, T.V.; Kociolek, J.P. Diatoms from hot springs from Kuril and Sakhalin Islands (Far East, Russia). In The Diatom World; Seckbach, J., Kociolek, J.P., Eds.; Springer: Dordrecht, The Netherlands, 2011; pp. 333-363.

183. Quintela, A.; Almeida, S.; Terroso, D.; Ferreira da Silva, E.; Forjaz, V.; Rocha, F. Diatom assemblages of thermal and mineral waters from volcanic environments in São Miguel Island, Azores. Diatom Res. 2013, 28, 407-417. 
184. Owen, R.B.; Renaut, R.W.; Jones, B. Geothermal diatoms: A comparative study of floras in hot spring systems of Iceland, New Zealand, and Kenya. Hydrobiologia 2008, 610, 175-192.

185. Lindemann, S.R.; Moran, J.J.; Stegen, J.C.; Renslow, R.S.; Hutchison, J.R.; Cole, J.K.; Dohnalkova, A.C.; Tremblay, J.; Singh, K.; Malfatti, S.A.; et al. The epsomitic phototrophic microbial mat of Hot Lake, Washington: Community structural responses to seasonal cycling. Front. Microbiol. 2013, 4, article 323.

186. Andersen, R.A. Diversity of eukaryotic algae. Biodivers. Conserv. 1992, 1, 267-292.

187. Guiry, M.D. How many species of algae are there? J. Phycol. 2012, 48, 1057-1063.

188. Grobbelaar, J.U. Physiological and technological considerations for optimising mass algal cultures. J. Appl. Phycol. 2000, 12, 201-206.

189. Pienkos, P.T.; Darzins, A. The promise and challenges of microalgal-derived biofuels. Biofuels Bioprod. Biorefin. 2009, 3, 431-440.

190. Chagoya, J.C.; Brown, J.; Gomez, M.S.; Zhang, J.; Jiang, Y.; Laverty, K.; Brown, L.; Quigg, A.; Burow, M.D. Media optimization and lipid formation of two native diatoms for cultivation in the Southwest Texas desert. J. Appl. Phycol. 2014, 26, 2075-2085.

191. Kim, J.K.; Kottuparambil, S.; Moh, S.H.; Lee, T.K.; Kim, Y.-J.; Rhee, J.-S.; Choi, E.-M.; Kim, B.H.; Yu, Y.J.; Yarish, C. Potential applications of nuisance microalgae blooms. J. Appl. Phycol. 2014, doi:10.1007/s10811-014-0410-7.

192. Jellyman, P.G.; Clearwater, S.J.; Clayton, J.S.; Kilroy, C.; Blair, N.; Hickey, C.W.; Biggs, B.J.F. Controlling the invasive diatom Didymosphenia geminata: An ecotoxicity assessment of four potential biocides. Arch. Environ. Contam. Toxicol. 2011, 61, 115-127.

193. Valdez-Ojeda, R.; González-Muñoz, M.; Us-Vázquez, R.; Narváez-Zapata, J.; Chavarria-Hernandez, J.C.; López-Adrián, S.; Barahona-Pérez, F.; Toledano-Thompson, T.; Garduño-Solórzano, G.; Escobedo-Gracia Medrano, R.M. Characterization of five fresh water microalgae with potential for biodiesel production. Algal Res. 2015, 7, 33-44.

194. Kopecky, J.; Schoefs, B.; Loest, K.; Stys, D.; Pulz, O. Microalgae as a source for secondary carotenoid production: A screening study. Arch. Hydrobiol. Suppl. 2000, 133, 153-168.

195. Meng, Y.; Yao, C.; Xue, S.; Yang, H. Application of Fourier transform infrared (FT-IR) spectroscopy in determination of microalgal compositions. Bioresour. Technol. 2014, 151, 347-354.

196. Wagner, H.; Jungandreas, A.; Fanesi, A.; Wilhelm, C. Surveillance of C-allocation in microalgal cells. Metabolites 2014, 4, 453-464.

197. Mahapatra, D.M.; Ramachandra, T.V. Algal biofuel: Bountiful lipid from Chlorococcum sp. proliferating in municipal wastewater. Curr. Sci. 2013, 105, 47-55.

198. Bougaran, G.; Rouxel, C.; Dubois, N.; Kaas, R.; Grouas, S.; Lukomska, E.; Le Coz, J.-R.; Cadoret, J.-P. Enhancement of neutral lipid productivity in the microalga Isochrysis affinis Galbana (T-Iso) by a mutation-selection procedure. Biotechnol. Bioeng. 2012, 109, 2737-2745.

199. Robert, S.; Mansour, M.P.; Blackburn, S.I. Metolachlor-mediated selection of a microalgal strain producing novel polyunsaturated fatty acids. Mar. Biotechnol. 2007, 9, 146-153. 
200. Kasbi-Chadli, F.; Boquien, C.-Y.; Simard, G.; Ulmann, L.; Mimouni, V.; Leray, V.; Meynier, A.; Ferchaud-Roucher, V.; Champ, M.; Nguyen, P.; et al. Maternal supplementation with n-3 long chain polyunsaturated fatty acids during perinatal period alleviates the metabolic syndrome disturbances in adult hamster pups fed a high-fat diet after weaning. J. Nutr. Biochem. 2014, 25, 726-733.

201. Juneau, P.; Dewez, D.; Matsui, S.; Kim, S.G.; Popovic, R. Evaluation of different algal species sensitivity to mercury and metolachlor by PAM-fluorometry. Chemosphere 2001, 45, 589-598.

202. Metting, F.B., Jr. Biodiversity and application of microalgae. J. Ind. Microbiol. 1996, 17, 477-489.

203. Ramesha, B.T.; Gertsch, J.; Ravikanth, G.; Priti, V.; Ganeshaiah, K.N.; Shaanker, R.U. Biodiversity and chemodiversity: Future perspectives in bioprospecting. Curr. Drug Targets 2011, 12, 1515-1530.

204. Sheehan, J.; Dunahay, T.; Benemann, J.; Roessler, P. A Look Back at the U.S. Department of Energy's Aquatic Species Program: Biodiesel from Algae; Close-Out Report NREL/TP-580-24190; National Renewable Energy Laboratory: Golden, CO, USA, 1998.

205. Tara Expeditions The Oceanomics Project. Available online: http://oceans.taraexpeditions.org/ en/m/science/news/the-oceanomics-project/ (accessed on 21 April 2015).

206. Fujii, K.; Matsunobu, S.; Takahashi, Y. Characterization of the new microalgal strains, Oogamochlamys spp., and their potential for biofuel production. Algal Res. 2014, 5, 164-170.

207. Ma, Y.; Wang, Z.; Yu, C.; Yin, Y.; Zhou, G. Evaluation of the potential of 9 Nannochloropsis strains for biodiesel production. Bioresour. Technol. 2014, 167, 503-509.

208. Tale, M.; Ghosh, S.; Kapadnis, B.; Kale, S. Isolation and characterization of microalgae for biodiesel production from Nisargruna biogas plant effluent. Bioresour. Technol. 2014, 169, 328-335.

209. Becerra, P.I.; Bustamante, R.O. The effect of herbivory on seedling survival of the invasive exotic species Pinus radiata and Eucalyptus globulus in a Mediterranean ecosystem of Central Chile. For. Ecol. Manag. 2008, 256, 1573-1578.

210. Boeuf, G.; Kornprobst, J.-M. Biodiversité et chimiodiversité marines/Biodiversity and marine chemodiversity. Biofutur 2009, 301, 28-32.

211. Newman, D.J.; Cragg, G.M. Natural products as sources of new drugs over the last 25 years. J. Nat. Prod. 2007, 70, 461-477.

212. Jiraskova, D.; Poulickova, A.; Novak, O.; Sedlakova, K.; Hradecka, V.; Strnad, M. High-throughput screening technology for monitoring phytohormone production in microalgae. J. Phycol. 2009, $45,108-118$.

213. Griffiths, M.J.; Harrison, S.T.L. Lipid productivity as a key characteristic for choosing algal species for biodiesel production. J. Appl. Phycol. 2009, 21, 493-507.

214. Barbour, M.T.; Gerritsen, J.; Snyder, B.D.; Stribling, J.B. Rapid Bioassessment Protocols for Use in Streams and Wadeable Rivers: Periphyton, Benthic Macroinvertebrates and Fish [EPA 841-B-99-002], 2nd ed.; Office of Water, U.S. Environmental Protection Agency: Washington, DC, USA, 1999.

215. Zhang, W.; Nielsen, D.R. Synthetic biology applications in industrial microbiology. Front. Microbiol. 2014, 5, doi:10.3389/fmicb.2014.00451.

216. Miyagawa-Yamaguchi, A.; Okami, T.; Kira, N.; Yamaguchi, H.; Ohnishi, K.; Adachi, M. Stable nuclear transformation of the diatom Chaetoceros sp. Phycol. Res. 2011, 59, 113-119. 
217. Dunahay, T.G.; Jarvis, E.E.; Roessler, P.G. Genetic transformation of the diatoms Cyclotella cryptica and Navicula saprophila. J. Phycol. 1995, 31, 1004-1012.

218. Fischer, H.; Robl, I.; Sumper, M.; Kroger, N. Targeting and covalent modification of cell wall and membrane proteins heterologously expressed in the diatom Cylindrotheca fusiformis (Bacillariophyceae). J. Phycol. 1999, 35, 113-120.

219. Poulsen, N.; Kröger, N. A new molecular tool for transgenic diatoms. Control of mRNA and protein biosynthesis by an inducible promoter-terminator cassette. FEBS J. 2005, 272, 3413-3423.

220. Muto, M.; Fukuda, Y.; Nemoto, M.; Yoshino, T.; Matsunaga, T.; Tanaka, T. Establishment of a genetic transformation system for the marine pennate diatom Fistulifera sp. strain JPCC DA0580-a high triglyceride producer. Mar. Biotechnol. 2013, 15, 48-55.

221. Apt, K.E.; Kroth-Pancic, P.G.; Grossman, A.R. Stable nuclear transformation of the diatom Phaeodactylum tricornutum. Mol. General Genet. 1996, 252, 572-579.

222. Zaslavskaia, L.A.; Lippmeier, J.C.; Kroth, P.G.; Grossman, A.R.; Apt, K.E. Transformation of the diatom Phaeodactylum tricornutum (Bacillariophyceae) with a variety of selectable marker and reporter genes. J. Phycol. 2000, 36, 379-386.

223. Niu, Y.-F.; Yang, Z.-K.; Zhang, M.-H.; Zhu, C.-C.; Yang, W.-D.; Liu, J.-S.; Li, H.-Y. Transformation of diatom Phaeodactylum tricornutum by electroporation and establishment of inducible selection marker. BioTechn. Rapid Dispatches 2012, doi:10.2144/000113881.

224. Ifuku, K.; Yan, D.; Miyahara, M.; Inoue-Kashino, N.; Yamamoto, Y.Y.; Kashino, Y. A stable and efficient nuclear transformation system for the diatom Chaetoceros gracilis. Photosynth. Res. 2015, 123, 203-211.

225. Shimogawara, K.; Fujiwara, S.; Grossman, A.; Usuda, H. High-efficiency transformation of Chlamydomonas reinhardtii by electroporation. Genetics 1998, 148, 1821-1828.

226. Kilian, O.; Benemann, C.S.E.; Niyogi, K.K.; Vick, B. High-efficiency homologous recombination in the oil-producing alga Nannochloropsis sp. Proc. Natl. Acad. Sci. USA 2011, 108, 21265-21269.

227. Radakovits, R.; Jinkerson, R.E.; Fuerstenberg, S.I.; Tae, H.; Settlage, R.E.; Boore, J.L.; Posewitz, M.C. Draft genome sequence and genetic transformation of the oleaginous alga Nannochloropsis gaditana. Nat. Commun. 2013, 4, 2356.

228. Radakovits, R.; Jinkerson, R.E.; Darzins, A.; Posewitz, M.C. Genetic engineering of algae for enhanced biofuel production. Eukaryot. Cell 2010, 9, 486-501.

229. Gong, Y.; Guo, X.; Wan, X.; Liang, Z.; Jiang, M. Characterization of a novel thioesterase (PtTE) from Phaeodactylum tricornutum. J. Basic Microbiol. 2011, 51, 666-672.

230. Trentacoste, E.M.; Shrestha, R.P.; Smith, S.R.; Gle, C.; Hartmann, A.C.; Hildebrand, M.; Gerwick, W.H. Metabolic engineering of lipid catabolism increases microalgal lipid accumulation without compromising growth. Proc. Natl. Acad. Sci. USA 2013, 110, 19748-19753.

231. Parker, K. Metabolic Network Construction Based on the Genome of the Marine Diatom Thalassiosira pseudonana and the Analysis of Genome-wide Transcriptome Data to Investigate Triacylglyceride Accumulation. M.Sc. Thesis, Moss Landing Marine Labs, San Jose State University, San Jose, CA, USA, 2013. 
232. Daboussi, F.; Leduc, S.; Maréchal, A.; Dubois, G.; Guyot, V.; Perez-Michaut, C.; Amato, A.; Falciatore, A.; Juillerat, A.; Beurdeley, M.; et al. Genome engineering empowers the diatom Phaeodactylum tricornutum for biotechnology. Nat. Commun. 2014, 5, doi:10.1038/ncomms4831.

233. Harrison, M.E.; Dunlop, M.J. Synthetic feedback loop model for increasing microbial biofuel production using a biosensor. Front. Microbiol. 2012, 3, 360.

234. Foo, J.L.; Jensen, H.M.; Dahl, R.H.; George, K.; Keasling, J.D.; Lee, T.S.; Leong, S.; Mukhopadhyay, A. Improving microbial biogasoline production in Escherichia coli using tolerance engineering. mBio 2014, 5, e0193214.

235. Jin, H.; Chen, L.; Wang, J.; Zhang, W. Engineering biofuel tolerance in non-native producing microorganisms. Biotechnol. Adv. 2014, 32, 541-548.

236. Heydarizadeh, P.; Marchand, J.; Chenais, B.; Sabzalian, M.R.; Zahedi, M.; Moreau, B.; Schoefs, B. Functional investigations in diatoms need more than a transcriptomic approach. Diatom Res. 2014, 29, 75-89.

237. Kutchan, T.M. Predictive metabolic engineering in plants: Still full of surprises. Trends Biotechnol. 2005, 23, 381-383.

238. Wang, B.; Li, Y.Q.; Wu, N.; Lan, C.Q. $\mathrm{CO}_{2}$ bio-mitigation using microalgae. Appl. Microbiol. Biotechnol. 2008, 79, 707-718.

239. Nikaido, H.; Takatsuka, Y. Mechanisms of RND multidrug efflux pumps. BBA-Proteins Proteomics 2009, 1794, 769-781.

240. Higgins, C.F. ABC transporters: From microorganisms to man. Annu. Rev. Cell Biol. 1992, 8, 67-113.

241. Rees, D.C.; Johnson, E.; Lewinson, O. ABC transporters: The power to change. Nat. Rev. Mol. Cell Biol. 2009, 10, 218-227.

242. Reyes, L.H.; Almario, M.P.; Kao, K.C. Genomic library screens for genes involved in $n$-butanol tolerance in Escherichia coli. PLoS ONE 2011, 6, e17678.

243. Tréguer, P.; Nelson, D.M.; van Bennekom, A.J.; DeMaster, D.J.; Leynaert, A.; Quéguiner, B. The silica balance in the world ocean: A reestimate. Science 1995, 268, 375-379.

244. Falkowski, P.G.; Katz, M.E.; Knoll, A.H.; Quigg, A.; Raven, J.A.; Schofield, O.; Taylor, F.J. The evolution of modern eukaryotic phytoplankton. Science 2004, 305, 354-360.

245. Sims, P.A.; Mann, D.G.; Medlin, L.K. Evolution of the diatoms: Insights from fossil, biological and molecular data. Phycologia 2006, 45, 361-402.

246. Moustafa, A.; Beszteri, B.; Maier, U.G.; Bowler, C.; Valentin, K.; Bhattacharya, D. Genomic footprints of a cryptic plastid endosymbiosis in diatoms. Science 2009, 324, 1724-1726.

247. Becker, B.; Hoef-Emden, K.; Melkonian, M. Chlamydial genes shed light on the evolution of photoautotrophic eukaryotes. BMC Evol. Biol. 2008, 8, Article Number 203.

248. Armbrust, E.V.; Berges, J.A.; Bowler, C.; Green, B.R.; Martinez, D.; Putnam, N.H.; Zhou, S.; Allen, A.E.; Apt, K.E.; Bechner, M.; et al. The genome of the diatom Thalassiosira pseudonana: Ecology, evolution, and metabolism. Science 2004, 306, 79-86.

249. Kociolek, J.P. Diatoms: Unique eukaryotic extremophiles providing insights into planetary change. Proc. Soc. Photo-Opt. Instrum. Eng. (SPIE) 2007, 6694, 66940S. 
250. Bertrand, M.; Schoefs, B.; Siffel, P.; Rohacek, K.; Molnar, I. Cadmium inhibits epoxidation of diatoxanthin to diadinoxanthin in the xanthophyll cycle of the marine diatom Phaeodactylum tricornutum. FEBS Lett. 2001, 508, 153-156.

251. Nguyen-Deroche, T.L.N.; Caruso, A.; Le, T.T.; Bui, T.V.; Schoefs, B.; Tremblin, G.; Morant-Manceau, A. Zinc affects differently growth, photosynthesis, antioxidant enzyme activities and phytochelatin synthase expression of four marine diatoms. Sci. World J. 2012, 2012, 982957.

252. Masmoudi, S.; Nguyen-Deroche, N.; Caruso, A.; Ayadi, H.; Morant-Manceau, A.; Tremblin, G.; Bertrand, M.; Schoefs, B. Cadmium, copper, sodium and zinc effects on diatoms: From heaven to hell-A review. Cryptogam. Algol. 2013, 34, 185-225.

253. Rohacek, K.; Bertrand, M.; Moreau, B.; Jacquette, B.; Caplat, C.; Morant-Manceau, A.; Schoefs, B. Relaxation of the non-photochemical chlorophyll fluorescence quenching in diatoms: Kinetics, components and mechanisms. Philos. Trans. R. Soc. B Biol. Sci. 2014, 369SI, 20130241.

254. Cheng, R.-1.; Feng, J.; Zhang, B.-X.; Huang, Y.; Cheng, J.; Zhang, C.-X. Transcriptome and gene expression analysis of an oleaginous diatom under different salinity conditions. Bioenergy Res. 2014, 7, 192-205.

255. Gacheva, G.V.; Gigova, L.G. Biological activity of microalgae can be enhanced by manipulating the cultivation temperature and irradiance. Cent. Eur. J. Biol. 2014, 9, 1168-1181.

256. Maeda, Y.; Sunaga, Y.; Yoshino, T.; Tanaka, T. Oleosome-associated protein of the oleaginous diatom Fistulifera solaris contains an endoplasmic reticulum-targeting signal sequence. Mar. Drugs 2014, 12, 3892-3903.

257. Burrows, E.; Bennette, N.; Carrieri, D.; Dixon, J.; Brinker, A.; Frada, M.; Baldassano, S.; Falkowski, P.; Dismukes, G. Dynamics of lipid biosynthesis and redistribution in the marine diatom Phaeodactylum tricornutum under nitrate deprivation. BioEnergy Res. 2012, 5, 876-885.

258. Taguchi, S.; Hirata, J.A.; Laws, E.A. Silicate deficiency and lipid synthesis of marine diatoms. J. Phycol. 1987, 23, 260-267.

259. Zhang, L.; Han, J.C.; Yang, G.P.; Zhu, B.H.; Pan, K.H. Association of triacylglyceride content and transcript abundance of genes involving in lipid synthesis of nitrogen deficient Phaeodactylum tricornutum. Chin. J. Oceanol. Limnol. 2014, 32, 397-402.

260. Badour, S.S.; Gergis, M.S. Cell division and fat accumulation in Nitzschia sp. grown in continuously illuminated mass cultures. Arch. Mikrobiol. 1965, 51, 94-102.

261. Beattie, A.; Percival, E.; Hirst, E.L. Studies on the metabolism of the Chrysophyceae. Comparative structural investigations on leucosin (chrysolaminarin) separated from diatoms and laminarin from the brown algae. Biochem. J. 1961, 79, 531-537.

262. Huang, B.; Marchand, J.; Moreau, B.; Lukomwska, E.; Bougaran, G.; Cadoret, J.-P.; Schoefs, B. Impact de l'approvisionnement en $\mathrm{CO}_{2}$ sur l'utilisation du carbone chez la diatomée Phaeodactylum tricornutum. In Book of Abstracts of the 33ème Colloque de l'Association des Diatomistes de Langue Française; l'Association des Diatomistes de Langue française: Thonon-les-Bains, France, 2014.

263. Ho, S.-H.; Huang, S.-W.; Chen, C.-Y.; Hasunuma, T.; Kondo, A.; Chang, J.-S. Characterization and optimization of carbohydrate production from an indigenous microalga Chlorella vulgaris FSP-E. Bioresour. Technol. 2013, 135, 157-165. 
264. Thomas, W.H.; Dodson, A.N.; Reid, F.M.H. Diatom productivity compared to other algae in natural marine phytoplankton assemblages. J. Phycol. 1978, 14, 250-253.

265. Jungandreas, A.; Costa, B.S.; Jakob, T.; von Bergen, M.; Baumann, S.; Wilhelm, C. The acclimation of Phaeodactylum tricornutum to blue and red light does not influence the photosynthetic light reaction but strongly disturbs the carbon allocation pattern. PLOS ONE 2014, 9, e99727.

266. Schoefs, B.; Rmiki, N.-E.; Rachadi, J.; Lemoine, Y. Astaxanthin accumulation in Haematococcus requires a cytochrome $\mathrm{P} 450$ hydroxylase and an active synthesis of fatty acids. FEBS Lett. 2001, $500,125-128$.

267. Klok, A.J.; Martens, D.E.; Wijffels, R.H.; Lamers, P.P. Simultaneous growth and neutral lipid accumulation in microalgae. Bioresour. Technol. 2013, 134, 233-243.

268. Yatsu, L.Y.; Jacks, T.J.; Hensarling, T.P. Isolation of spherosomes (oleosomes) from onion, cabbage, and cottonseed tissues. Plant Physiol. 1971, 48, 675-682.

269. Davidi, L.; Katz, A.; Pick, U. Characterization of major lipid droplet proteins from Dunaliella. Planta 2012, 236, 19-33.

270. Nojima, D.; Yoshino, T.; Maeda, Y.; Tanaka, M.; Nemoto, M.; Tanaka, T. Proteomics analysis of oil body-associated proteins in the oleaginous diatom. J. Proteome Res. 2013, 12, 5293-5301.

271. Zhang, X.Q.; Dubacq, J.P.; Alfsen, A. Biochemical and cytological evidence for the stimulation of clathrin-coated (vesicle) formation by exogenous folic acid in Dunaliella salina (Chlorophyta). J. Phycol. 1993, 29, 203-209.

272. Hamano, S. On the oil of the living egg of salmon, Oncorhynchus keta. Bull. Jpn. Soc. Sci. Fish. 1951, 17, 47-52.

273. Targett-Adams, P.; Chambers, D.; Gledhill, S.; Hope, R.G.; Coy, J.F.; Girod, A.; McLauchlan, J. Live cell analysis and targeting of the lipid droplet-binding adipocyte differentiation-related protein. J. Biol. Chem. 2003, 278, 15998-16007.

274. Bostrom, P.; Rutberg, M.; Ericsson, J.; Holmdahl, P.; Andersson, L.; Frohman, M.A.; Boren, J.; Olofsson, S.O. Cytosolic lipid droplets increase in size by microtubule-dependent complex formation. Arterioscler. Thromb. Vasc. Biol. 2005, 25, 1945-1951.

275. Nagayama, M.; Uchida, T.; Gohara, K. Temporal and spatial variations of lipid droplets during adipocyte division and differentiation. J. Lipid Res. 2007, 48, 9-18.

276. Watanabe, T.; Thayil, A.; Jesacher, A.; Grieve, K.; Debarre, D.; Wilson, T.; Booth, M.; Srinivas, S. Characterisation of the dynamic behaviour of lipid droplets in the early mouse embryo using adaptive harmonic generation microscopy. BMC Cell Biol. 2010, 11, 38.

277. Dou, W.; Zhang, D.; Jung, Y.; Cheng, J.-X.; Umulis, D.M. Label-free imaging of lipid-droplet intracellular motion in early Drosophila embryos using femtosecond-stimulated Raman loss microscopy. Biophys. J. 2012, 102, 1666-1675.

278. Long, A.P.; Manneschmidt, A.K.; VerBrugge, B.; Dortch, M.R.; Minkin, S.C.; Prater, K.E.; Biggerstaff, J.P.; Dunlap, J.R.; Dalhaimer, P. Lipid droplet de novo formation and fission are linked to the cell cycle in fission yeast. Traffic 2012, 13, 705-714.

279. Dalhaimer, P. Lipid droplet organelle distribution in populations of dividing cells studied by simulation. Phys. Biol. 2013, 10, 036007. 
280. Baffes, J.; Kose, A.; Ohnsorge, F.; Stocker, M.; Chen, D.; Cosic, D.; Gong, X.; Huidrom, R.; Vashakmadze, E.; Zhang, J.; et al. Understanding the plunge in oil prices: Sources and implications. In Global Economic Prospects: Having Fiscal Space and Using It; World Bank Publications: Washington, DC, USA, 2015; pp. 155-168.

281. Baumeister, C.; Kilian, L. Understanding the decline in the price of oil since June 2014. Available online: http://papers.ssrn.com/sol3/papers.cfm?abstract_id=2557316 (accessed on 21 April 2015).

282. Rahemtulla, K. World Manipulated Into Buying Saudi Oil. Available online: http://www. wallstreetdaily.com/2014/11/07/u-s-saudi-arabia-oil/ (accessed on 21 April 2015).

283. Sabino, A.M. New York fracking outlook still gloomy. Nat. Gas Electr. 2015, 31, $20-25$.

284. Golden, J.M.; Wiseman, H.J. The fracking revolution: Shale gas as a case study in innovation policy. Emory Law J. 2015, 64, 955-1040.

285. Dale, B.E.; Anderson, J.E.; Brown, R.C.; Csonka, S.; Dale, V.H.; Herwick, G.; Jackson, R.D.; Jordan, N.; Kaffka, S.; Kline, K.L. Take a closer look: Biofuels can support environmental, economic and social goals. Environ. Sci. Technol. 2014, 48, 7200-7203.

286. Gendy, T.S.; El-Temtamy, S.A. Commercialization potential aspects of microalgae for biofuel production: An overview. Egypt. J. Pet. 2013, 22, 43-51.

287. Aluya, J. Biofuels has become disruptive technology to the energy market. Biofuels 2015, 5, 457-467.

288. Kirkby, J.; Carslaw, K.S. Variations of galactic cosmic rays and the Earth's climate. In Solar Journey: The Significance of Our Galactic Environment for the Heliosphere and Earth: The Significance of Our Galactic Environment for the Heliosphere and Earth; Frisch, P.C., Ed.; Springer: Dordrecht, The Netherlands, 2006; pp. 349-397.

289. Haigh, J.D. Solar variability and climate. In Space Weather; Lilensten, J., Ed.; Springer: The Netherlands, 2007; Volume 344, pp. 65-81.

290. Hanslmeier, A. Space weather and climate. In The Sun and Space Weather; Springer: The Netherlands, 2007; Volume 347, pp. 143-173.

291. Previdi, M.; Polvani, L.M. Climate system response to stratospheric ozone depletion and recovery. Q. J. R. Meteorol. Soc. 2014, 140, 2401-2419.

292. O'Riordan, T. Fracking, sustainability, and democracy. Environ. Sci. Policy Sustain. Dev. 2015, $57,2-3$.

293. Ipsen, D. The lifecycle of oil: Problems and conflicts. In Competition and Conflicts on Resource Use; Hartard, S., Liebert, W., Eds.; Springer: Switzerland, 2015; pp. 61-74.

294. Upham, P.; Dendler, L. Scientists as policy actors: A study of the language of biofuel research. Environ. Sci. Policy 2015, 47, 137-147.

295. Fresewinkel, M.; Rosello, R.; Wilhelm, C.; Kruse, O.; Hankamer, B.; Posten, C. Integration in microalgal bioprocess development: Design of efficient, sustainable, and economic processes. Eng. Life Sci. 2014, 14, 560-573.

296. Murphy, D.J. The implications of the declining energy return on investment of oil production. Philos. Trans. R. Soc. Lond. A Math. Phys. Eng. Sci. 2014, 372, 20130126.

297. Shen, Y. Carbon dioxide bio-fixation and wastewater treatment via algae photochemical synthesis for biofuels production. RSC Adv. 2014, 4, 49672-49722. 
298. Wikipedia Artificial photosynthesis. Available online: http://en.wikipedia.org/wiki/Artificial_ photosynthesis (accessed on 21 April 2015).

299. Mandal, S.; Mallick, N. Microalga Scenedesmus obliquus as a potential source for biodiesel production. Appl. Microbiol. Biotechnol. 2009, 84, 281-291.

300. Dahiya, A. Integrated approach to algae production for biofuel utilizing robust algal species. In The Science of Algal Fuels: Phycology, Geology, Biophotonics, Genomics and Nanotechnology; Gordon, R., Seckbach, J., Eds.; Springer: Dordrecht, The Netherlands, 2012; pp. 83-100.

301. Topf, M.; Tavasi, M.; Kinel-Tahan, Y.; Iluz, D.; Dubinsky, Z.; Yehoshua, Y. Algal oils: Biosynthesis and uses. In The Science of Algal Fuels: Phycology, Geology, Biophotonics, Genomics and Nanotechnology; Gordon, R., Seckbach, J., Eds.; Springer: Dordrecht, The Netherlands, 2012; pp. 193-214.

302. Shifrin, N.S.; Chisholm, S.W. Phytoplankton lipids: Interspecific differences and effects of nitrate, silicate and light-dark cycles. J. Phycol. 1981, 17, 374-384.

303. Chen, Y.-C. The biomass and total lipid content and composition of twelve species of marine diatoms cultured under various environments. Food Chem. 2012, 131, 211-219.

304. Pittman, J.K.; Dean, A.P.; Osundeko, O. The potential of sustainable algal biofuel production using wastewater resources. Bioresour. Technol. 2011, 102, 17-25.

305. Mahapatra, D.M.; Chanakya, H.; Ramachandra, T. Euglena sp. as a suitable source of lipids for potential use as biofuel and sustainable wastewater treatment. J. Appl. Phycol. 2013, 25, 855-865.

306. Mahapatra, D.M.; Chanakya, H.N.; Ramachandra, T.V. Bioremediation and lipid synthesis through mixotrophic algal consortia in municipal wastewater. Bioresour. Technol. 2014, 168, 142-150.

307. Fathi, A.A.; Azooz, M.M.; Al-Fredan, M.A. Phycoremediation and the potential of sustainable algal biofuel production using wastewater. Am. J. Appl. Sci. 2013, 10, 189-194.

308. Chanakya, H.N.; Mahapatra, D.M.; Sarada, R.; Abitha, R. Algal biofuel production and mitigation potential in India. Mitig. Adapt. Strateg. Glob. Chang. 2013, 18, 113-136.

309. Brownbridge, G.; Azadi, P.; Smallbone, A.; Bhave, A.; Taylor, B.; Kraft, M. The future viability of algae-derived biodiesel under economic and technical uncertainties. Bioresour. Technol. 2014, 151, 166-173.

310. Mobile Algae Refinery: VALORIE, the Versatile ALgae On-site Raw Ingredient Extractor. Available online: https://www.youtube.com/watch?v=gkoxA74q25c (accessed on 21 April 2015).

311. Wikipedia Multi-objective optimization. Available online: https://en.wikipedia.org/wiki/ Multi-objective_optimization (accessed on 21 April 2015).

(C) 2015 by the authors; licensee MDPI, Basel, Switzerland. This article is an open access article distributed under the terms and conditions of the Creative Commons Attribution license (http://creativecommons.org/licenses/by/4.0/). 